\title{
A ninth century earthquake-induced landslide and flood in the Kashmir Valley, and earthquake damage to Kashmir's Medieval temples
}

\author{
Roger Bilham • Bikram Singh Bali
}

Received: 28 April 2013 / Accepted: 12 August 2013 / Published online: 22 August 2013

(C) The Author(s) 2013. This article is published with open access at Springerlink.com

\begin{abstract}
An entry in the Tarikh-i-Hassan records that in 883 AD during the reign of King Avantivarman (855-883) an earthquake in Kashmir triggered a landslide that impounded the River Jhelum and flooded the Kashmir Valley. Kalhana's Rajatarangini provides abundant details about how the ninth century engineer Suyya both cleared the natural dam, drained the valley and instituted numerous irrigation works. We identify the landslide(s) responsible for this Medieval flood and from twentieth century discharge statistics of the Jhelum calculate that it would have taken at least 2 years to flood the Kashmir Valley to near Anantnag. This presents a chronological difficulty, for the causal earthquake could not have occurred in the last 4 months of Avantivarman's rule, and we conclude that it must have occurred much earlier, perhaps before the start of his reign. The flood occurred during a period of widespread temple building using massive uncemented limestone megablocks, capped by monolithic multi-ton roofs. Many of these magnificent temples, now in ruinous condition, are located close to the shores of the inferred Medieval flood level, suggesting that the transport of construction materials for these temples may have been ferried by barge from distant quarries. Historians and archaeologists have attributed the partial collapse of these temples to malicious damage by subsequent occupants of the valley, but the misalignment of blocks at lower levels within each edifice in recent earthquakes suggests that their lateral offsets are the result of jostling during prolonged shaking in historical earthquakes. From the serendipitous entrapment of datable materials beneath fallen blocks from Kashmir's ninth century temples we can, in principle, identify the times of historical earthquakes. We chose the ruined Sugandhesa temple near Patan to test this hypothesis. Preliminary results indicate collapse in the tenth or eleventh century, and significant damage in 1885 , with at least one intervening earthquake possibly in the seventieth century.
\end{abstract}

R. Bilham $(\varangle)$

Department of Geological Sciences, University of Colorado,

Boulder, CO 80309-0399, USA

e-mail: bilham@colorado.edu

B. S. Bali

Department of Geology and Geophysics, University of Kashmir, Jammu and Kashmir 190 006, India 
Keywords Historical earthquakes · Landslides · Earthquake-induced floods · Archaeological damage · Medieval Kashmir

\section{Introduction}

The Kashmir Valley is an enclosed basin measuring roughly $130 \mathrm{~km}$ SE by $40 \mathrm{~km}$ NE into which five rivers and numerous minor streams drain (Fig. 1), and from which a single fluvial exit from the valley has been cut by the Jhelum through a narrow gorge near the town of Baramula. The total catchment area of Kashmir streams exceeds $15,000 \mathrm{~km}^{2}$ including several snowfields and glaciers, and the resulting discharge is strongly seasonally dependent. At Baramula monthly means between 1922 and 2000 indicate an annual mean discharge of $237 \pm 70 \mathrm{~m}^{3} \mathrm{~s}^{-1}$, with a peak discharge averaging more that $400 \mathrm{~m}^{3} \mathrm{~s}^{-1}$ for the 4 months of snow melt starting in April, and $<100 \mathrm{~m}^{3} \mathrm{~s}^{-1}$ in months of snow accumulation in December and January (Vörösmarty et al. 1998; Wetlands International 2007).

From historical accounts reproduced later in the text we deduce that a landslide dam was formed no further than $10 \mathrm{~km}$ downstream from Baramula. For the first $10 \mathrm{~km}$ of its passage west of Baramula the Jhelum falls by $<10 \mathrm{~m}$ through a channel whose width varies from 50 to $90 \mathrm{~m}$, confined by steep mountains rising in places more than $1.5 \mathrm{~km}$ above the river bed.

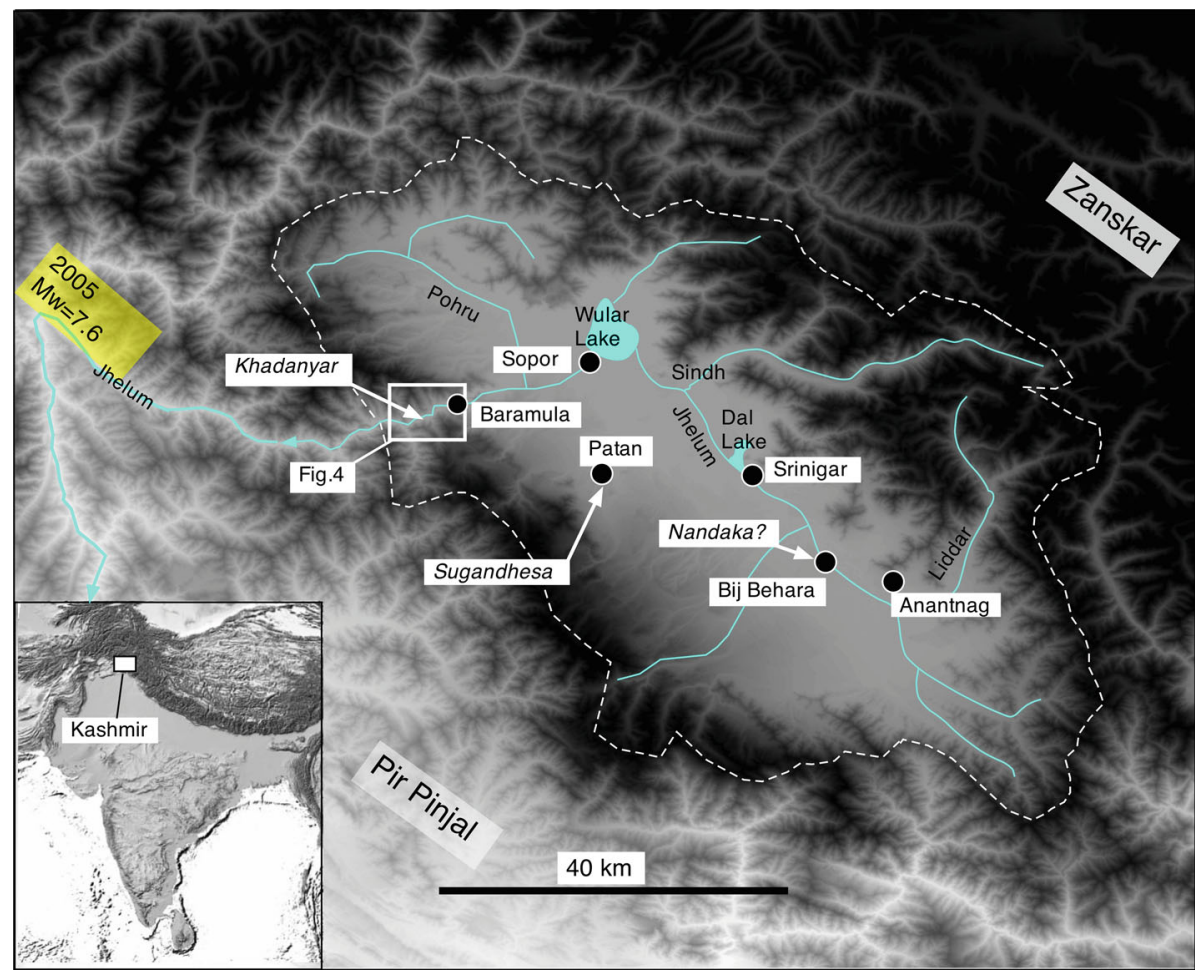

Fig. 1 Jhelum catchment (principal streams in blue) and place names mentioned in the text. River valleys are light grey amid high elevations $>2,000 \mathrm{~m}$ shaded black. Rupture area of 2005 Kashmir earthquake shaded yellow. Location of Fig. 4a, b indicated by box 


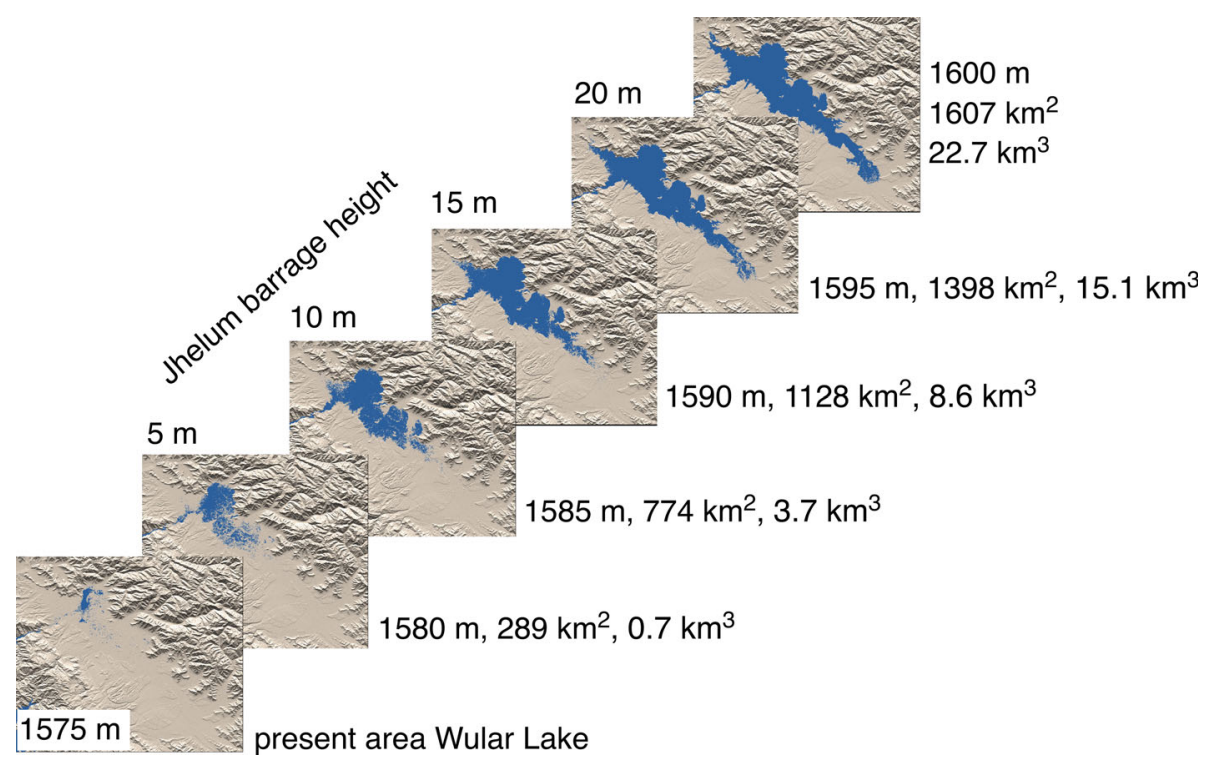

Fig. 2 Increase in flooded area $\left(\mathrm{km}^{2}\right)$ and cumulative lake volume $\left(\mathrm{km}^{3}\right)$ resulting from incrementing the height of a natural dam on the Jhelum downstream from Baramula in $5 \mathrm{~m}$ intervals to a maximum height of $25 \mathrm{~m}$. The zero datum is the present exit level for the Jhelum at Baramula of $1,575 \mathrm{~m}$

The south-facing slopes of the Jhelum gorge are generally devoid of forest and are scarred by occasional traces of former landslides. In some places the river channel is incised through banks of landslide debris rising locally $>40 \mathrm{~m}$ above stream levels, suggesting that landslides have temporarily halted or slowed the flow of the river. A prolonged blockage of the river anywhere in the $10 \mathrm{~km}$ stretch of river west of Baramula by a dam with a crest height of 10-30 m above present channel levels may be guaranteed to flood low-lying districts of the Kashmir Valley. In Fig. 2 we illustrate the area flooded and lake capacity at $5 \mathrm{~m}$ intervals, and in Fig. 3 we calculate the time taken to flood the valley to various depths using 19731977 discharge data (Vörösmarty et al. 1998). The rate of rise for the first $10 \mathrm{~m}$ of flooding depends on the season - a landslide dam in December would raise flood waters $10 \mathrm{~m}$ in the valley over $\approx 200$ days, whereas a landslide dam during the melt season starting in April may take half as long depending on temperatures and precipitation. At higher flood levels the rate of rise slows considerably due to the greatly increased area of the growing lake. Using recent Jhelum discharge data it is not possible to fill the valley to Bij Behara in $<2$ years, and since we ignore seepage through the dam the rates of rise in Figs. 2 and $3 b$ constitute minimum estimates. The calculations were based on higher-than-average discharge rates, and almost certainly higher discharge rates may have occurred in Kashmir's past that would hasten the rise of flood levels, but to raise the level $20 \mathrm{~m}$ above the present level of Wular Lake a sustained $1,000 \mathrm{~m}^{3} \mathrm{~s}^{-1}$ discharge would be needed for 6 months $(50 \%$ greater than the highest recorded monthly mean).

Historical accounts [Kalhana's epic Rajatarangini in 1150 (Stein 1898) and Tarikh-iHassan (Hassan's history) written in 1896] mention a landslide in the second half of the ninth century that dammed the Jhelum Valley downstream from Baramula, where it exits the Kashmir Valley. Rising waters restrained by this natural dam eventually flooded the Kashmir Valley to Bij Behara, near Anantnag, resulting in a famine and displacing low lying populations to higher ground. According to our calculations the time taken to flood 

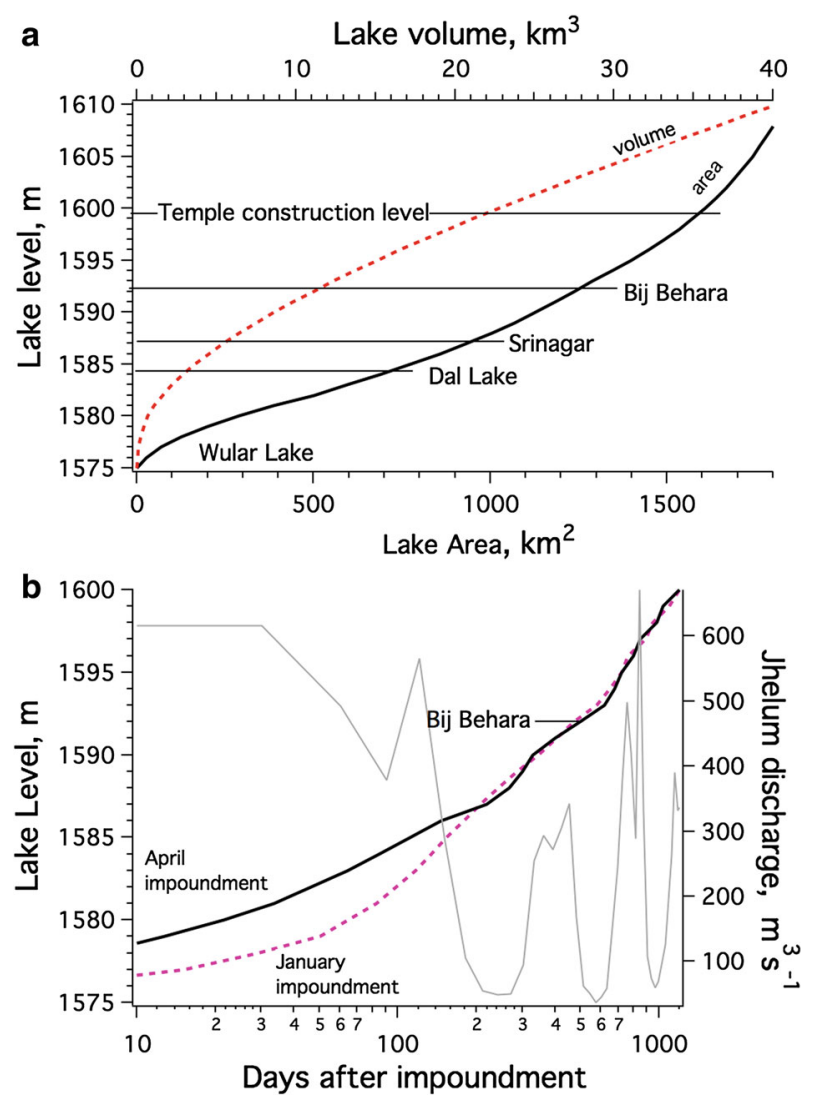

Fig. 3 a Lake capacity (dashed) versus lake area for the Kashmir Valley for floods 0-35 m above basin exit level. Seven Medieval temples are located at $\approx 1,600 \mathrm{~m}$ elevation. b Time taken (logarithmic time scale) for the valley to flood to the $1,600 \mathrm{~m}$ contour ( $25 \mathrm{~m}$-depth) using realistic discharge rates (grey line $=$ observed April 1973-July 1977 discharge at Baramula). The dashed line assumes impoundment following a landslide-induced dam that occurs in late December (minimum discharge), whereas the solid line assumes impoundment starting in April at the time of maximum discharge

the Kashmir Valley to Bij Behara $(17 \mathrm{~m}$ above the level of the Jhelum where it exits the valley), cannot be $<2$ years whether flooding commences in January or in April using typical discharge rates (Fig. 3b). Although it is possible to envisage extreme summer melt rates exceeding those tested $\left(650 \mathrm{~m}^{3} \mathrm{~s}^{-1}\right)$ it is unlikely that Medieval discharge rates during winter months were substantially higher than in the past century. We note that Srinagar, the capital of Kashmir, would be flooded to a depth of approximately $5 \mathrm{~m}$ at the time that flood waters onlapped Bij Behara (Fig. 3a).

According to these historical accounts, the flood waters were abated by breaching the landslide dam with the help of villagers eager to recover pots of coins thrown into the water as an incentive by King Avantivarman's engineer Suyya. This same engineer, Suyya, is attributed with the design and completion of numerous drainage and irrigation schemes in Medieval Kashmir some of which can be still identified. The city of Sopor (Suyyapur) at the exit of the Jhelum near Wular Lake, was founded by, and named after, Suyya.

Widespread hydraulic engineering activities occurred in the Kashmir Valley during the time of King Avantivarman (855-883 AD), who was also responsible for the construction 
of numerous temples, the most famous of which are those at Avantipur some $30 \mathrm{~km}$ east of Srinagar (Kak 1933). The details of Suyya's engineering works were described by Kalhana in sufficient detail for Stein (1899) to reconstruct the former course of the Jhelum near its intersection with the Sind river, and the probable location of the landslide dam that caused extensive flooding of the valley (near Khadinyar in Fig. 1). Despite the detailed nature of some of the accounts several inconsistencies in the timing of the irrigation and flood control measures, and the date of the earthquake that Hassan indicates triggered the landslide, are apparent in the written histories that we next address.

\section{Accounts of the ninth century earthquake and landslide}

We first note that the effects of the causal earthquake and its effects on structures in the valley are not described except in terms of flooding of villages and farms. Earthquakes are common in Kashmir and only significant earthquakes are mentioned in the Tarikh-i-Hassan, hence the association of the landslide with an earthquake suggests that it was large enough to be worthy of mention. Although, Stein (1898) makes no mention of an earthquake we consider it unlikely that Hassan's (1896) source was describing shaking arising from the descent of the landslide itself, owing to the long periods associated with landslide potential energy release to which people are not sensitive (Ambraseys and Bilham 2012). We consider that the causal earthquake may have been a moderate magnitude event $(\mathrm{Mw}>6)$ insufficient to damage buildings and cause other damage worth of historical note. Building styles at the time were based on wood frame construction, or wattle-and-daub, thatched-roof dwellings, both in the cities and the villages, that would most probably have survived a major earthquake. Intensity VII+ accelerations in the 1885 Patan $\mathrm{MW}<6.5$ earthquake that did destroy wood frame buildings in Baramula resulted in landslides in the Jhelum valley that blocked road traffic for a week until they were cleared (Jones 1885), but these slides did not dam the Jhelum. There are no historical data describing a large historical earthquake within several $100 \mathrm{~km}$ of the valley in the ninth century.

\section{Uncertainty in the date of the earthquake}

The earthquake is often referred to as occurring in $883 \mathrm{AD}$ (BS 940) which was the last year of the reign of Avantivarman (855-883) and the first year of the reign of his successor Samkaravarman (883-902). However, this presents an obvious difficulty, for King Avantivarman died in March $883 \mathrm{AD}$, when discharge rates are typically low, leaving insufficient time for the valley to fill and drain before his death. Bashir et al. (2009) note that the same earthquake is described in Tarikh-i-Kabir and Wajeez-ut-Tawarikh, presumably from the same sources as those available to Hassan, but they state the date as $844 \mathrm{AD}$, which one of the authors (personal communication, 2013) concedes as probably an erroneous date conversion. Our March 883 date is derived from the conversion of the third day of the Month of Asadha in the Laukika year 3959 (Stein 1899, Book 5, verse 126) to Common Era dates using the conversions of Sewell and Dikshit (1896, Table 1, page xxxviii), and those of Prinsep (1858). Due to the hydraulic constraints associated with accumulation and drainage $15-20 \mathrm{~m}^{3}$ of flood waters, the flood and its causal earthquake must have developed prior to $883 \mathrm{AD}$, and if we are to believe that significant engineering works in the Kashmir Valley were funded and undertaken by Avantivarman and his engineer Suyya it appears probable that the earthquake and its flood occurred many years earlier. It would be surprising if Suyya's activities ceased upon the death 
Avantivarman, but no mention is made of his activities during the reign of Samkaravarman in the Rajatarangini (Stein 1898). In following sections we discuss the timing of the flood and its drainage in greater detail.

\section{Location of the earthquake-triggered landslide}

Two secondary accounts of the ninth century earthquake and flood are available - that due to Hassan (1833-1898) who writes in Persian script and compiles numerous earlier works, none earlier than the sixteenth century, and that due to Kalhana written in 1150, of which a Sanskrit copy from 1685 has survived (Stein 1892). Hassan first mentions a semi-mythical earthquake dated at approximately $1250 \mathrm{BC}$ that is unrelated to the $883 \mathrm{AD}$ flood. His second entry describes the $883 \mathrm{AD}$ earthquake, landslide and flood and its drainage.

Iyengar and Sharma (1996, 1998) and Iyengar et al. (1999) translate Pir Ghulan Hassan Shah's Tarikh-i-Hassan as follows:

The second calamity of a nocturnal earthquake occurred during the reign of Raja Avantivarman in Bikram Sambet 940 (883 AD). Boulders from the mountainous ridge of Khadahneyar on the Baramula side rolled into the bed of the river Behat (Jhelum) and consequently the flow of the river was blocked. The ground level near Bijbehra was inundated and the entire adjoining villages and cultivable land, were destroyed. Then by the efforts of the intelligent, Suyya, stone conglomerates of the mountain were removed from the river bed and the water was set free. The ground level emerged as previous.

(Tarikh-i-Hassan, tf. 1690. 170a)

An independent literal translation was kindly provided from the Persian text by Prof. Ebad Ghanbari of the University of Tabriz.

The second event occurred in the time of Raja Avantivarman (940). At night a massive earthquake happened and a part of "Kehade Nahar" a mountain above Baramula fell as a landslide into the river so that a natural dam was created in the river because of which floods covered the ground. All villages and farms were completely destroyed, then according to wise ideas, stones of the mountain were taken out of the deepest part of the water and then we could see the surface of the ground again.

Hassan's history appears to indicate the specific year for the earthquake as the last year of the reign of Avantivarman, who died in March 883. However, as we note above (Fig. 3), if this earthquake dammed the Jhelum, the resulting flood could not reach to Bij Behara, $17 \mathrm{~m}$ above normal river levels within these last 3 months of the Avantivarman administration. To do so would require a discharge an order of magnitude higher than any observed. The time to drain the valley imposes an additional time limit - we calculate below that the shortest time to drain a $>15 \mathrm{~km}^{3}$ flood from the Kashmir Valley given reasonable assumptions (a discharge of $\approx 1,000 \mathrm{~m}^{3} \mathrm{~s}^{-1}$ ) is of the order of 6 months. Our calculations thus suggest that a flood to Bij Behara cannot be created and dispelled between January and March. To overcome this difficulty we assume that the historian was loosely indicating the end of Avantivarman's reign, rather than the date of the earthquake.

The Tarikh-i-Hassan account also provides a specific location by mentioning the "ridge of Khadniyar" above Baramula. Khadniyar (Khadanyar) on present-day maps (Fig. 4a, b) is backed by a low ridge to its south which rises westward from the river level to $2,300 \mathrm{~m}$, and continues north of the village as a ridge towards Baramula exceeding $3,000 \mathrm{~m}$. The river 

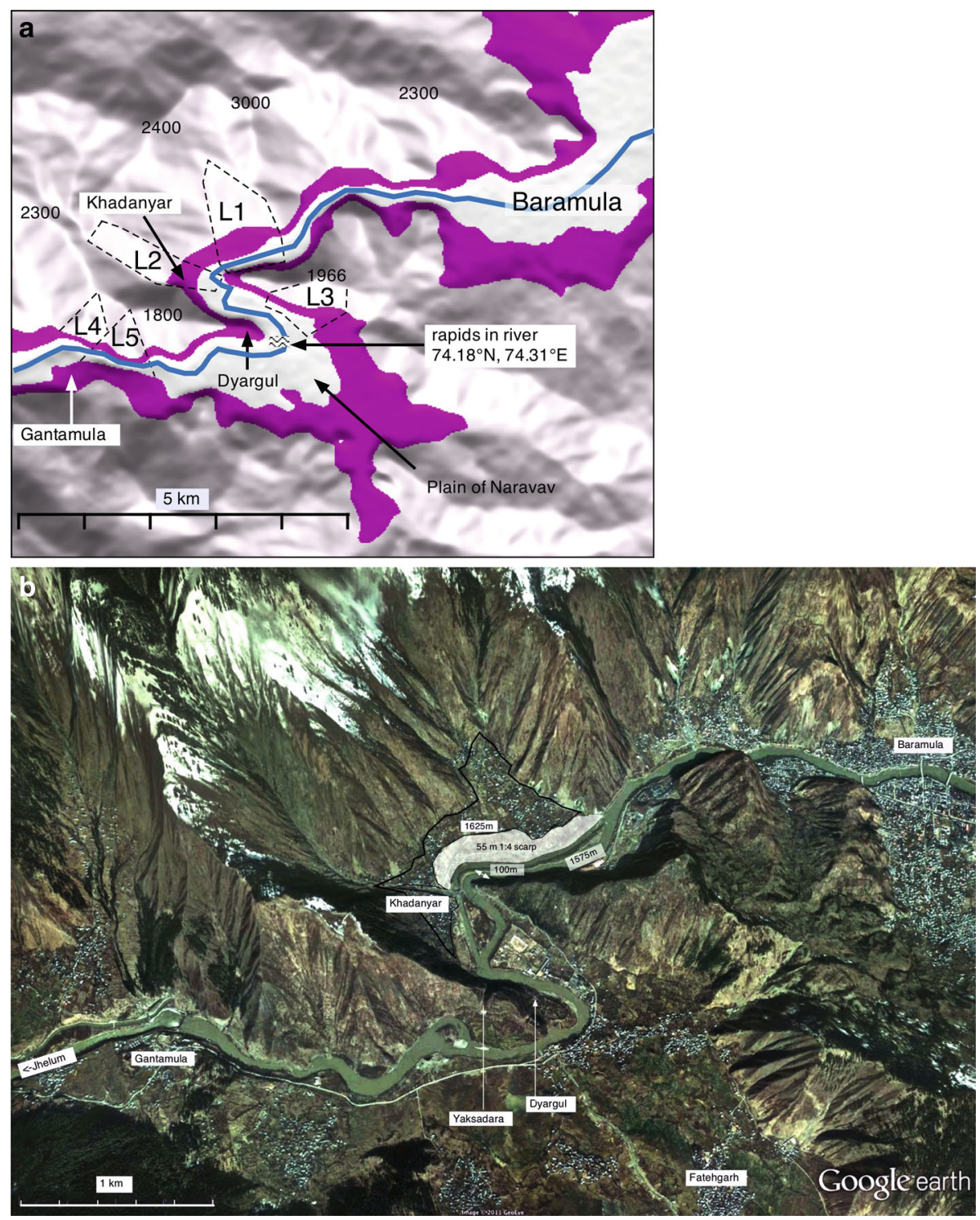

Fig. 4 a The path of the Jhelum downstream from Baramula with river terraces above 1,590m and below $1,650 \mathrm{~m}$ shaded. The lower contour $(1,590 \mathrm{~m})$ is the minimum height of a landslide required to flood Bij Behara in the Kashmir Valley. South-facing scars are indicated L1-L5 with numbered spot heights in m. Note the constricted channel width below L1, L4 and L5. AV-shaped notch affords passage through the Dyargul ridge near the point of the arrow, which was identified by Stein (1899, p. 85) as Yaksadara-the demon's cleft. The river falls from 1,575 m near Baramula to 1,560 west of Gantamula, but most of its descent occurs below the rapids at Dyargul, mapped by Montgomerie Montgomerie $(1858,1886)$ b Google Earth oblique view of the Jhelum gorge below Baramula. The scarp eroded by the river through the landslide deposit NE of Khadanyar (shaded) attains a height $>50 \mathrm{~m}$

channel NE of the present village of Khadniyar cuts through a $20 \mathrm{~m}$ high triangular-shaped present-day alluvial fan (Fig. 4, L1 fed by numerous small streams. The $1 \mathrm{~km}$-long incised section along the front surface of the fan reveals it to include unsorted blocks of angular 
debris with dimensions up to several meters typical of a landslide deposit. This stretch NE of Khadniyar is $<60 \mathrm{~m}$ wide, and a collapse here is consistent with the location of the landslide described. The problem of equating L1 with the ninth century landslide, however, is that this would pond water above Khadniyar, which is not favored by Kalhana's account (Stein 1898) which we now introduce.

Kalhana's account, written barely 200 years after the event does not mention an earthquake at all. The abatement of the flood is described in his fifth book of rhyming verses, the Rajatarangini (River of Kings) translated from the Sanskrit by several authors, the most incisive being that of Marcus Aurelius Stein (1898). Stein's translation is important because not only did he have an uncorrupted copy of the manuscript to work from, but he recognized that Kalhana's nomenclature of the geography of the valley (Stein 1897, 1899) corresponded well with nineteenth century mapping published by Montgomerie $(1858,1886)$, and that this correspondence permitted the disambiguation of many of the stanzas of the text. Kalhana's Sanskrit text was composed between 1148 and 1150AD, and Stein's designated codex archetypus took the form of a birch-bark copy in Sarada script transcribed in 1685, a critical rendition of which was published by Stein (1892). Stein was able to identify the date and writer of this codex by recognizing the handwriting of Rajanaka Ratnakantha, a scholar who was responsible for copies of several other historical works. He also succeeded in discerning subsequent corrections in colophons that suggested its accuracy had been carefully compared with earlier copies, or even with Kalhana's original birch-bark manuscript, which in 1898 (and now) was no longer available. English translations of the Rajatarangini prior to that undertaken by Stein are unreliable because they are derived from an 1835 copy of the Sarada codex written in Devendara script whose transcription had introduced numerous misunderstandings and corruptions. In the extracts below we note that Ranjit Sitaram Pandit's (1935) translation (written while a political prisoner) and Stein's (1898) translation of the Suyya legend do not differ in any substantial detail.

The Suyya legend is prefaced by a mythical description of his origin, and identifies his rise to prominence as starting when King Avantivarman learned that Suyya had been overheard to claim that he was able to drain the flood that then plagued the Kashmir Valley. Avantivarman offered Suyya the funding he requested to undertake this task, but to everyone's surprise Suyya proceeded to throw large quantities of the king's coins into the flood waters.

85. After dropping there a pot full of money, at a village called Nandaka, which was submerged in the flood he hurriedly turned back

86. Though the councilors said "That Suyya is surely only a madman", the king, when he heard this account became interested in watching the end of these proceedings.

Stein admits to be unable to identify the village of Nandaka, but based on verse 84, which indicates that Suyya headed south of Srinagar by boat to the district of Maraz, speculates that it may possibly be near the "old Nandi canal north of Kaimuh" (Fig. 1). This would place the village between Anantnag and Bij Behara at the extreme SE end of the flood, west of the confluence of the Liddar and Jhelum (Fig. 1). The water depth here would have been relatively shallow, and hence Stein's location is unconvincing. This is because in verse 108 we read that after the remediation of the flood, the Nandaka hoard "which he had dropped in an unfathomable depth of water, was found in the midst of the dry land when the village of Nandaka emerged from the waters." For the non-retrieval of coins beneath "unfathomable" flooded waters one would imagine that a depth of at least $4 \mathrm{~m}$ would be required, if not considerably more, which might have occurred closer to Srinagar, but not at the distant extremity of the flood as it inched its way to the SE end of the valley. 
In verse 85 we learn that Suyya hurriedly returns from the south and heads north $65 \mathrm{~km}$ as the crow-flies to Baramula. Today the journey from Bij Behara to Baramula takes no more than a few hours by road, but Suyya was apparently in a boat accompanied by spectators: the king, his councilors, and presumably numerous mystified villagers. In 1873 the ferry journey took $48 \mathrm{~h}$ downstream and 4 days upstream (Bates 1873), and even given an extensive flood, it would have been impossible to take many short cuts because branches of the forests bordering the Jhelum would have protruded above the flood waters. One might suppose that Suyya's journey with support from the King could have been undertaken in no less than half a day, but sooner were the village of Nandaka closer to Srinagar.

87. On reaching Kramarajya, the locality called Yaksadara, he threw with both hands, money into the water.

88-89. There, where the rocks which had rolled down from the mountains lining both river banks had compressed the Vitasta and made its waters turn backwards in whirls, the famine stricken villager then searched for the money, dragged out the rocks from the river, and thus cleared the bed of the Vitasta.

Based on an appended colophon in his codex archetypus, (Stein 1897, and 1899, footnote p. 197) equates Yaksadara with a narrow $160 \mathrm{~m}$ long dry valley $\left(34.1866^{\circ} \mathrm{N}, 74.2998^{\circ} \mathrm{E}\right)$ through the rocky spur named Dyargul south of the village of Khadniyar (Fig. 4a, b). Dyar means "money" in Kashmiri adding credence to a tradition associated with the Suyya legend, although Stein found no memory of the legend among villagers when he visited the village in 1892. Stein notes that the rapids near the end of this spur, which are identified on Montgomerie's (1858) map but now obscured by the artificial level of the Jhelum restrained by barrages downstream, was the terminus for river traffic in the valley. A field inspection of the current setting of these rapids indicate they represent a bed-rock nick-point in the river profile typically associated with active reverse faulting in the Himalaya (Seeber and Gornitz 1983).

However, the association of a landslide dam with this rocky spur, and mention of vorticity in the waters ponded by a landslide raises two technical issues. First, the relief bordering the river at Dyargul is quite modest ( $150 \mathrm{~m}$ to the south and $300 \mathrm{~m}$ to the north) compared to stretches of the river $1 \mathrm{~km}$ upstream and downstream from the present village of Khadniyar (Khadanyar), which are backed by large areas of unstable hillside (Fig. 4). Second, the upstream water would have been 20-25 m deep for the flood waters to have reached Bij Behara, and the description of whirlpools is inconsistent with the deep still waters ponded by the dam whose breach is described in verses 89-93. We perceive no way that rapid currents could occur upstream from the dam until the dam was at least partially breached, and we therefore conclude that the passage describing the turbulent waters is descriptive license by the historian, or a description of seepage or flow following the partial breach of the dam by an artificial spillway.

Landslides occur most commonly on south-facing slopes in the Himalaya and Pamir (Ambraseys and Bilham 2012). Such slopes are most exposed to freeze-thaw conditions and are largely devoid of forest. In Fig. 4a we identify five steep south-facing scars and the inferred paths of landslides that could potentially block the Jhelum. Of these L1 is the largest but we consider its location too far east to be consistent with Suyya's second deposit of coins. A landslide at L2 would have buried any town in its path, but it is possible that a new town with the same name may have been established long after the landslide. The present village of Khadniyar lies at 1,590-1,600 m elevation and a historical landslide here could have blocked the $300 \mathrm{~m}$ width of the Jhelum where it follows an acute bend from westward to southeast flow. 
The southern slope at L3 does not well fit the description since it is not on the Baramula side of the Khadniyar ridge (Baramula lay on the north bank of the Jhelum in the ninth century, subordinate to the south bank town of Huskapura), and much of the river terrace adjoining the river below L1 lies below 1,590 m. For similar reasons collapse of the southern side of the Dyargul spur (Fig. 4) is not considered capable of blocking the river since the river valley here is too wide, and the relief insufficient for debris to have resulted in sufficiently high and broad dam to its south.

Landslides L4 and L5 are possible candidates near Gantamula, where numerous unsorted blocks can be found within the terrace south of the river, some with dimensions of several meters. The river cuts a $30 \mathrm{~m}$ channel through this terrace. Ponding of the river at Gantamula (1,590 elevation) would have resulted in a $1 \mathrm{~km}$ wide lake south of Dyargul possibly flooding the Buddhist convent of Kitsahom (Krtyasrama), but not the temple ruins higher in the Plain of Naravav (Narvav), but this poses the question why Suyya would have thrown coins into the river $3 \mathrm{~km}$ upstream from the dam he wanted cleared. It is possible that there were no towns closer than Khadniyar with sufficient labor, and that curious Khadniyar villagers were viewing his activities from the village road that passes through the Yaksadara cutting. This interpretation is consistent with the wording of Kalhana's verse 87.

\section{Unblocking the dam}

Kalhana's next several verses discuss the engineering details of Suyya's unblocking of the landslide dam. Kalhana's explanation indicates that the removal of the landslide occurred in four stages that we interpret as follows: initial lowering by debris removal, construction of a coffer dam which blocked the river for a week, construction of a lined channel, and then destruction of the coffer dam to cause a hydraulic surge to clear a path through the landslide.

90-91. After he had in this manner artfully drained off that water for two or three days, he had the Jhelum dammed up in one place by workman. The whole river was blocked up by Suyya for seven days by the construction of a stone dam, a wonderful work. 92-93. After having the river bed cleared at the bottom and stone walls constructed to protect it against rocks which might roll down, he removed the dam. Then the stream, flowing to the ocean, set out on its course in haste, as if eagerly longing for the sea after its detention.

94. When the water left it the land was covered with mud and with wriggling fishes, and this resembled the night sky, which when free from clouds, displays black darkness and the stars.

This interesting sequence offers several interpretations of which we propose the following. The waters appear to have been lowered in verse 89 sufficient for the villagers to recover some but perhaps not all of the coins thrown into the waters near Yaksadara. Had this first stage of clearing the dam been attended by, say, a $5 \mathrm{~m}$ lowering in the crest of the dam, it would have permitted the drainage of roughly one third of the volume of the floodwaters then stored in the Kashmir Valley, but this could not have occurred in less than a few weeks given the low hydraulic head, large reservoir volume and restricted channel width. This estimate is based on the following considerations. The observed discharge rate of natural dams with an initial hydraulic head of $<20 \mathrm{~m}$ during breaching is typically below $2,000 \mathrm{~m}^{3} \mathrm{~s}^{-1}$ (Walder and O'Connor 1997). The flow rate, however, after breaching a dam near Khadinyar would have been moderated by the hydraulic conditions in the Jhelum valley above the dam, that we assume were similar to those that exist at present. Assuming a steady discharge 

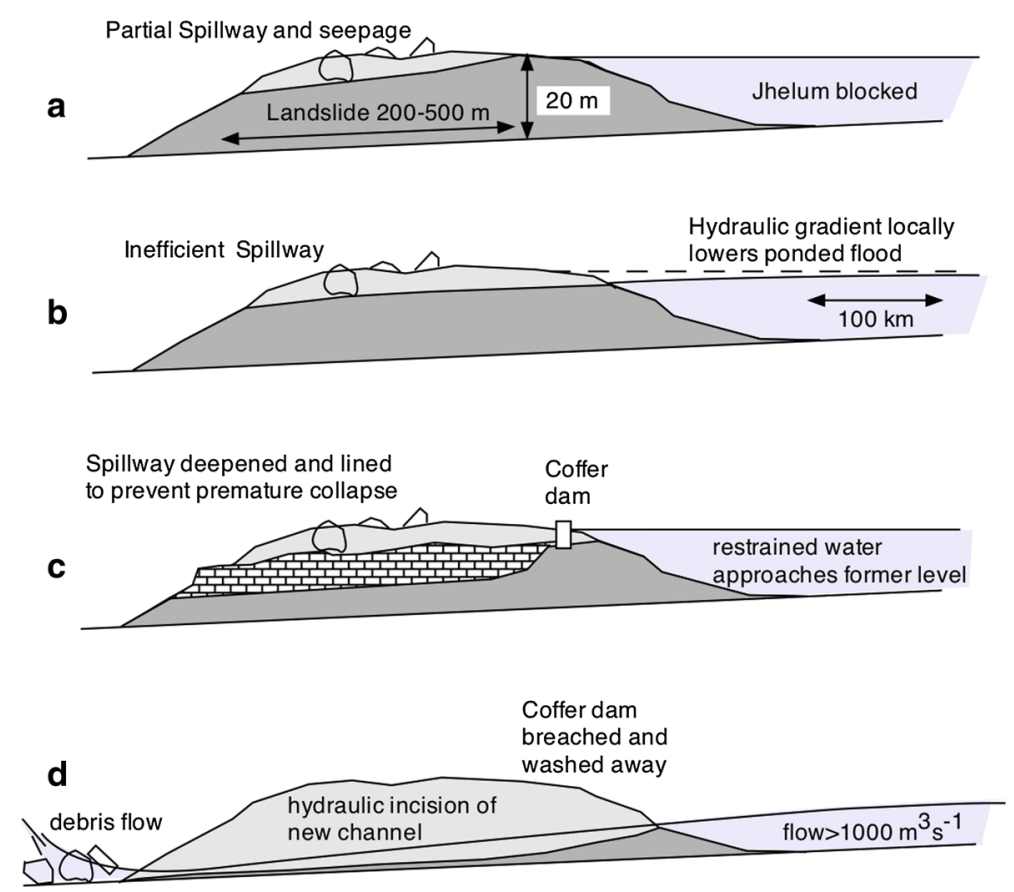

Fig. 5 Possible sequence adopted for removal of the Medieval Jhelum landslide. Suyya's initial spillway (a, b) which drained for 3 days may have been inefficient and difficult to deepen, causing him to build a coffer dam (c), and to dig and line a narrow spillway through the bulk of the slide, avoiding large rocks too heavy to move. By destroying the dam (d) after forming a deep spillway through the landslide, he was able to enlist the erosive power of fast running water to deepen and widen the spillway, leading ultimately to the return of the stream channel close to its former level

of $1,000 \mathrm{~m}^{3} \mathrm{~s}^{-1}(30 \%$ higher than any peak monthly discharge recorded in the Jhelum at Baramula 1922-2000) would drain the water stored up the Bij Behara level in $\approx 6$ months. Emptying the valley of flood waters is non-linear in time due to the depth-variable volume and reduction in hydraulic head, but a lowering of flood waters from 1,595 to $1,590 \mathrm{~m}$ at $1,000 \mathrm{~m}^{3} \mathrm{~s}^{-1}$ would take approximately 2 months.

We suspect that this initial stage was in fact a description of the clearance of an ineffective spillway through the crest of the landslide, possibly in the presence of seepage. An example of seepage of the Hattian Bala natural dam during reservoir impoundment following the 2005 Kashmir earthquake is furnished by Dunning et al. (2007). In the historical account we are not told whether the flood waters had crested and were spilling over the dam, or whether a channel had been excavated through its crest to initiate drainage. A channel avoiding the largest blocks was presumably possible, but it may have been difficult to deepen if Suyya's workers were simultaneously permitting the water to drain through the crest of the dam, and to clear boulders. Recognizing that it was not possible to remove the larger blocks or further deepen the channel, Suyya deemed it necessary to hold the water back with a temporary dam and to excavate a deeper channel. This may have been facilitated because initial drainage described in verse 89 had presumably resulted in a transient hydraulic gradient throughout the river, lowering the level temporarily at the landslide several meters below the equipotential level in the distant reaches of the Kashmir Valley (Fig. 5b). This locally-lowered level permitted him to construct a stone dam, presumably on the upstream crest of the landslide. The dam would 
have needed to be only few meters high and only as wide as the recently constructed spillway, and the water level would have started to rise behind it quite rapidly from the reservoir of water stored in the Kashmir Valley. It is possible that the coffer dam was being constructed as fast as the water equilibrated.

With the waters now checked by a temporary dam Suyya proceeded to dig a channel deeper than before. This may explain the need for a stone lining as described in verse 91 . We consider that the lining was needed to prevent the channel from collapsing during his excavation, rather than during the planned hydraulic release or subsequent channeling of the river. The lining of the deepened artificial spillway could not have been very substantial, or very extensive, and there is, of course, no evidence for its existence nowadays. Kalhana allows just 7 days for the lowering of its bed and the construction of its walls. During the 7 day construction of the spillway the waters behind the temporary dam may have equilibrated to an equipotential surface probably not substantially lower than before the earlier breach.

The destruction of the temporary but "wonderful" stone dam (verses 91 and 93) could have been triggered by the removal of a few key parts of the edifice, which would then have collapsed the entire structure. The resulting gush of water through the deepened spillway was presumably sufficient to cause catastrophic erosion of the landslide, and to incise the river back close to its former channel level. We envisage that it may have taken 2-6 months to drain the entire Kashmir Valley.

\section{Suyya's irrigation and drainage schemes}

In verses 95-107 Kalhana describes numerous flood diversion channels, dykes and irrigation channels that were apparently sanctioned throughout the valley after the removal of the landslide. We do not propose to go into the details of these works except to note that they could hardly have been completed in the present day with heavy machinery in less than a decade. A $67 \mathrm{~km}$-long stone-lined embankment is described along the banks of the Jhelum (Jhelum $=$ Vitasta, Book 5, v. 103 and footnote; Stein 1898). This work occurred in addition to diversions in the course of the Jhelum near the Buddhist plateau city of Parihasapura, and the construction of overflow channels, the drainage of swamps, and the provision of circular-walled flood defenses for some of the low lying villages. Simultaneously Suyya was busy with irrigation measures that led to enhanced crop production. This all would have required considerable funding and manpower and must have acted as a boost to the Medieval economy.

95. Whenever he heard of the breaches by inundation during the disastrous flood, in each one of them he constructed new channels for the Vitasta.

96. With several canals thrown out from the original main stream, the river shone like a black female snake with numerous hoods resting on one body.

97-98. To the left of Tigrami, the Sindhu, to the right, the Vitasta, the two formerly met near Vainyasvamin; to this day there exists in the precincts of Srinagara the confluence of these two great rivers, indestructible even at the end of the Kalpa, which was the enterprise of Suyya.

99-100. There were situated on either bank of the confluence of Phalpura and Parihasapura the shrines of Visnuvamin and Vainyasvamin which are extant, whereas on the bank of the confluence at the present time which reaches the precincts of Sundaribhavana there is Hrsi-Kesa Yogasayin. 
101. To this day are to be seen ancient trees, growing on the edges of the old canals of the rivers, with marks of the boat ropes fastened by the Nisadas.

A problem arises with the timing of some of these works that is not addressed by Kalhana. Since the low lying villages had only recently emerged from the receding waters, and we are not told how long the flood had been in existence, it is not clear what caused Suyya to instigate flood mitigation measures in the low lying villages near the path of the Jhelum. Either a historical tradition of flooding prevailed among Kashmiri families, or the returning villagers were continuing to be bothered by annual floods, or Suyya had instituted a pro-active scheme for flood mitigation based on perceived potential flood levels in order to encourage villagers to return to their former villages. Despite the obvious admiration with which his contemporaries held his achievements, it appears that Suyya's measures were insufficient to mitigate a disastrous flood that occurred only 34 years later- the 917 AD flood (Kalhana, Book 5 V270-V271).

\section{Timing of the "883" AD flood and implications for temple construction in Kashmir}

In Book 5, Verse 71 Kalhana prefaces his descriptions of the exploits of Suyya with a statement that prior to the reign of Avantivarman the valley was flooded and the price of rice was 1,050 Dinnaras per khari ( $1 \mathrm{khari} \approx 88 \mathrm{~kg}$ ), five times higher than in times of normal (clement) farming conditions (verse 116). During his reign, as a result of Suyya's hydraulic engineering, which consisted of both drainage and irrigation, the price of rice fell to 36 Dinnaras per khari, a factor of six lower than the regular price. Thus the time of Avantivarman is distinguished by Kalhana as a time of national prosperity and easy living, a welcome and peaceful transition from corrupt former rulers.

Temple building is not mentioned as part of Suyya's job description, but we know this was a major activity during the reign of Avantivarman, and Kak (1933) suggests that the first of the temples at Avantipur (Avantisvara) was constructed before he ascended to the throne. The construction of the second temple, Avantisvami, may have started shortly after Avantivaran's inauguration. In extolling the virtues of Avantivarman, Kalhana notes that the newly exhumed land area in the Kashmir Valley invited the establishment of many new villages. In verse 121 "thousands" of new settlements are claimed to have been established by Avantivarman and others (ministers and later kings), but this is surely an exaggeration. However, it suggests that Avantivarman inherited a flooded Kashmir Valley, and left it greatly increased in arable land, and land area suitable for development.

We are persuaded that the establishment of Avantivarman's reputation as a well-liked king encouraging the welfare of the people through domestic improvements, and funding the works of his engineer Suyya, is unlikely to have been established late in his reign. It appears very probable a flood existed at the time of his inauguration, which implies that the date of the earthquake mentioned as causing the landslide on the Jhelum by Tarikh-i-Hassan may have been equated by that historian with the wrong ruler. We suggest that the drainage of the Kashmir flood may have occurred in the first decade of Avantivarman's tenure. Had this occurred around 860 or 870 AD, this would have given Suyya a decade or two to supervise construction of the numerous embankments, canals, overflow channels and irrigation works, and establish the city of Sopor as described in Kalhana's verses 95-121 in the years following the elimination of the flood.

If these deductions are correct, then the earthquake that caused the landslide very probably occurred during the reign of a former ruler, possibly Ajitapida. Unfortunately Kalhana's 


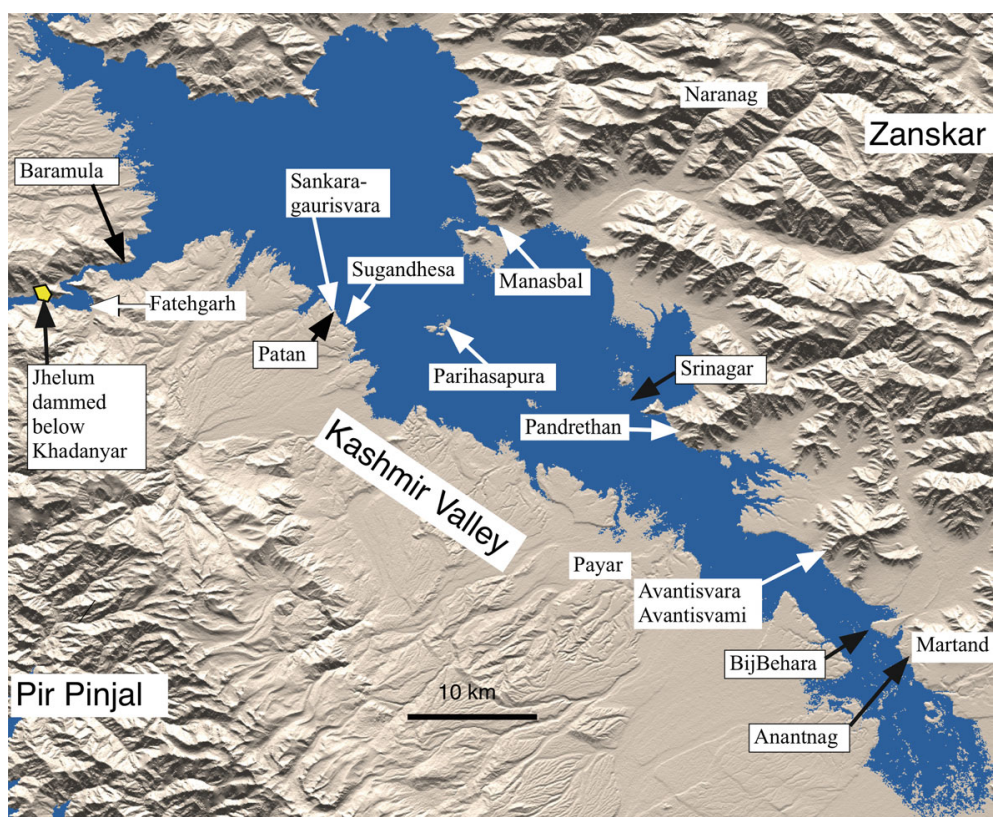

Fig. 6 Location of Kashmir's stone temples relative to the shoreline of a 1,600 m flood. Black arrows indicate towns, white arrows indicate temples. Seven of the ten limestone-monolith temples indicated lie close to the $1,600 \mathrm{~m}$ shoreline. The Buddhist temple complex of Parihasapura lies on an island. Only Naranag, constructed from local granite, and Martand, constructed of limestone, are located in the hills

history of Kashmir prior to the inauguration of Avantivarman lacks detail, and no mention of an earthquake occurs in his accounts of the preceding 500 years.

The potential existence of a flooded Kashmir Valley early in the reign of Avantivarman has interesting implications for temple construction that we briefly explore. In Fig. 6 we note that several of Kashmir's temples are serendipitously located near the high stand of the former lake that extended up to Bij Behara. Of the ten temples identified on the map, the foundations of seven lie close to the $1,600 \mathrm{~m}$ contour. Many of the blocks used in the temples measure $1 \times 1 \times 3 \mathrm{~m}^{3}$ and some measure $3 \times 3 \times 1 \mathrm{~m}^{3}$, suggesting that construction materials weighing upwards of nine metric tons may have been transported within the valley by barge. Limestone is quarried presently near Pandrethan, on the banks of the current Jhelum, and this may have been the source materials for the construction.

The temples on the NE edge of the Kashmir Valley lie close to the Jhelum but those in Patan lie a substantial distance from river transport. Following the death of Avantivarman in 883 AD Samkaravarman (883-902 AD) was appointed king. A brief civil war ensued in which he defeated an opposing pretender to the throne, followed by a successful war of conquest to neighboring kingdoms. Samkaravarman established his capital at Patan where he founded two temples: the Sankaragaurisvara temple named after the King, and the Sugandhesa temple named after his queen. A third temple was constructed in Patan by his minister but all trace of this third temple has been lost. There is no certainty, however, that the minister's temple is in fact not one of the two temples that remains.

Kalhana scathingly relates (book 5, Verse 161) that the Patan temples were constructed from masonry blocks pillaged from the Buddhist temples at Parihasapura and Stein (1899) mentions that this may have been partly faciliated by river transport. The process of 
transporting blocks from the Parihasapura plateau to the $1,600 \mathrm{~m}$ contour near Sugandhesa would have been much simplified had the valley been flooded at the time of Samkaravarman construction efforts since both Parihasapura and Sugandhesa, separated by just $8.5 \mathrm{~km}$, lay on the shoreline of the lake shown in Fig. 5. However, if Suyya's flood abatement and irrigation schemes had been completed during Avantivarman's rule, the flood waters would have receded by the time Samkaravarman started his temple construction.

It is possible, though unlikely, that a second earthquake and flood occurred at the end of Avantivarman's rule, consistent with the passage from Tarikh-i-Hassan reproduced above, but Kalhana makes no mention of the return of floods until 917 AD, 15 years after the death of Samkaravarman, and 2 years after the execution of his queen.

An alternative hypothesis is that the Parishasapura masonry had been barged to Patan for temple construction during the time of Avantivarman. This also is considered unlikely for the obvious reason that Avantivarman, according to Kalhana was an honorable and tolerant king, who would presumably have considered it beneath his dignity to destroy the Buddhist temples in Parihasapura. However, it is possible that the pillaging occurred before Avantivarman came to power, and that either a stockpile of construction materials was awaiting assembly at Patan, a shoreline close to Parihasapura, or that the temples were reconstructed from former temple ruins already assembled from recycled Parihasapura ruins. A major earthquake in the valley in late Buddhist times could have destroyed numerous Buddhist monuments in the valley, some of which may have remained as ruins for centuries, providing a tempting source of salvageable materials for future architects. We consider this hypothesis below.

\section{Damage to Medieval temples in the Kashmir Valley}

In this section we examine archaeological evidence for the dates of construction and partial destruction of the Sugandhesa temple. We preface this discussion with examples for the style of earthquake damage that has occurred to several megablock temples in the valley, and argue that the style of collapse is incremental. Blocks are shaken loose from the top of each structure, and lateral displacement and drift of blocks occurs within the walls of a structure. Obviously, some temple structures must have undergone greater, perhaps catastrophic collapse, and these are no longer available for our study. Those that remain suffered minor, or no damage in 1885, and only one of Kashmir's temples, the Detha Temple in Bandi (Dathamandir, $34.1218^{\circ} \mathrm{N}, 74.0777^{\circ} \mathrm{E}$ ) close to Uri, was damaged in the $2005 \mathrm{Mw}=7.6$ earthquake. The entrance portal at Detha Bandi partly collapsed in this earthquake, similar to incremental damage from the 1885 earthquake described in the Patan temples below.

The concept of a self-supporting Roman structural-arch was not known to Medieval Kashmir architects although they recognized its shape as an architectural feature. Hence arches, most commonly expressed in the form of a trefoil arch, were carved from single horizontal stone beam, and supported by cantilevered beams embedded in contiguous pillars. The absence of segmented arches gave the resulting structures considerable resilience to earthquakes. Additionally the blocks of many of the walls were assembled from blocks from a range of sizes and shapes, which were tailor-made to fit the lower or adjacent course. The interlocking nature of these walls resulted in a tendency for structures to resist damage in moderate shaking.

Many of the temples of Kashmir that have survived are ruined, but we note that to raze them fully to the ground would not require much effort by a determined vandal. Blocks weighing a few tons could have relatively easily been displaced with ropes and levers in the past 1,000 years, especially if assisted by horses or elephants deployed by vindictive conquerors 
or religious zealots. The survival of so many Medieval structures to the present time thus challenges the commonly held view that damage to the temples in the Kashmir Valley was undertaken during a relentless quest of destruction by Sikander Butshikan (1389-1413) and a Hindu convert named Suha in the late thirteenth century. Together they are supposed to have systematically demolished the Hindu and Buddhist temples of Kashmir, earning Sikander the appendage "Iconoclast" for his destructive rampage. Damage to the Avantipur temples looked so extensive to Cunningham (1848) that he suggested that gunpowder had been employed to hasten their ruin, arguing that this may have been available in fourteenth century Kashmir. Sahni (1918), however, finds mention in an historical Persian document that Sikander may have ruined the temples by setting fire to piles of timber within them. This may explain why the masonry of many of the temples remains structurally undamaged. Sikander the Iconoclast's reputation for a spoiler may have come from the incendiary damage to temple furnishings that would have no doubt been perceived as extreme. For various reasons discussed below we favor the partial destruction of the stone skeleton of temples to earthquake shaking.

Willful destruction of temples in past times appears to have occurred only in terms of recycling materials for later construction, as clearly occurred on the Parihasapura plateau (Stein 1899). From a seismic point of view, it is rather likely that the removal of temple materials most naturally would have occurred following a damaging earthquake that reduced an otherwise intact structure to an abandoned heap of dressed stones.

We discuss three temples that illustrate styles of structural damage in the Kashmir Valley that we interpret as the result of shaking by earthquakes.

\section{Pandrethan temple $\left(74.860^{\circ} \mathrm{E}, 34.056^{\circ} \mathrm{N}\right)$}

The Shiva temple at Pandrethan $\approx 3 \mathrm{~km}$ east of Srinagar, Kashmir is believed to have been constructed AD 913-921 (Kak 1933). It consists of a symmetrical stone structure measuring $5.5 \mathrm{~m}$ on each side, and $\approx 7.5 \mathrm{~m}$ high, aligned $\mathrm{N} 20 \mathrm{~W}$ with an elaborate portal on each side. Its stone-block pyramidal roof is interrupted by an overhanging step and four small windows. The temple was constructed from close-fitting dressed limestone blocks, with no cement between courses. Four squat equally-spaced columns support a hollow pyramidal roof of
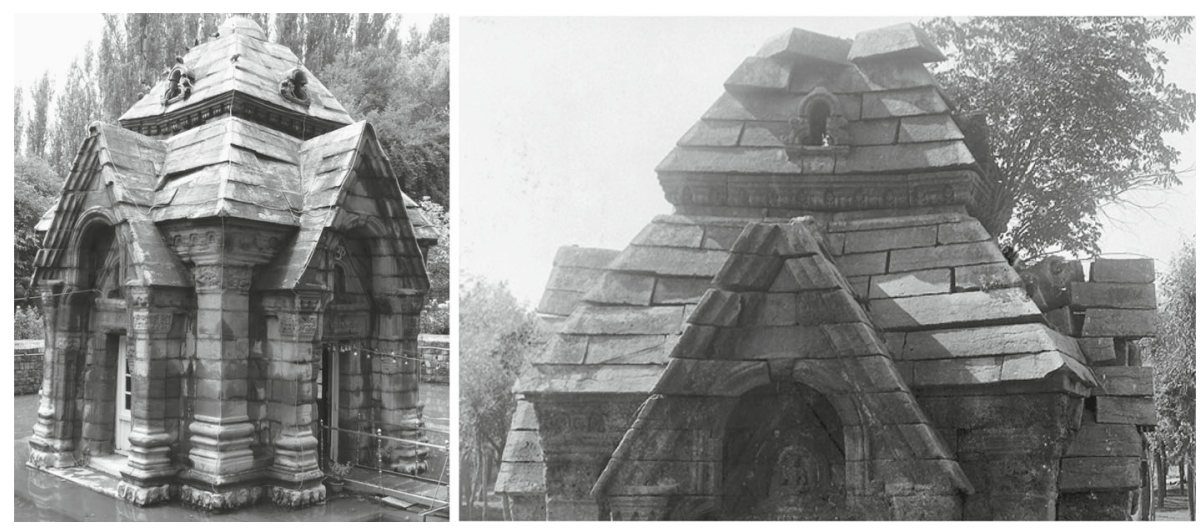

Fig. 7 The Pandrethan temple in 2006 (repaired in the twentieth century), with a close-up of the roof taken in 1903 after the 1885 earthquake. An earlier photograph in 1868 shows an identical misalignment of roof blocks (Bilham et al. 2010) indicating that earthquakes before 1885 were responsible for the observed displacements 
tapered blocks. Large triangular blocks first cover the stout corner walls and overhang the interior corners. The resulting enclosed diagonal square space is overlain by blocks parallel to the sides of the structure, and these in turn are covered by a single ceiling block. The lower surface of the ceiling block (probably the heaviest single stone in the structure) is embellished with delicate carvings.

Damage to the Pandrethan temple near Srinagar has occurred by lateral translation and shedding of blocks from the roof as the result of jostling of the entire structure (Fig. 7). The lower courses of the structure are not misaligned but the structure has lost its capstone. Since the ornate internal roof decoration appears to be undamaged, and damage to lower courses is largely absent, total collapse and subsequent reconstruction does not appear to have occurred (Bilham et al. 2010).

\section{Payar temple $\left(33.861^{\circ} \mathrm{N},{\left.74.9402^{\circ} \mathrm{E}\right)}\right.$}

This temple differs substantially in construction method, though not in style, from the earlier temples in the valley. The walls are single slabs with their longest dimension vertical. The temple is one of the smallest in the valley measuring $7 \mathrm{~m}$ high and $3 \mathrm{~m}$ at its base, and although it mimics the Kashmir temples found elsewhere, it differs in that it has an internal domed roof. Ornamentation on the temple suggests a date of construction in the eleventh century (Kak 1933).

The temple is specifically of interest because it is the only temple that Kak (1933) specifically identifies as having been vandalized since its construction. He notes its roof is offset by some $3 \mathrm{~cm}$ (Fig. 8), as the result of a "feeble attempt to dismantle" the structure, apparently unaware that lateral block drift, often accompanied by rotation, is a characteristic feature of shaking in an earthquake. A small lateral offset has also occurred in one of the foundation blocks.

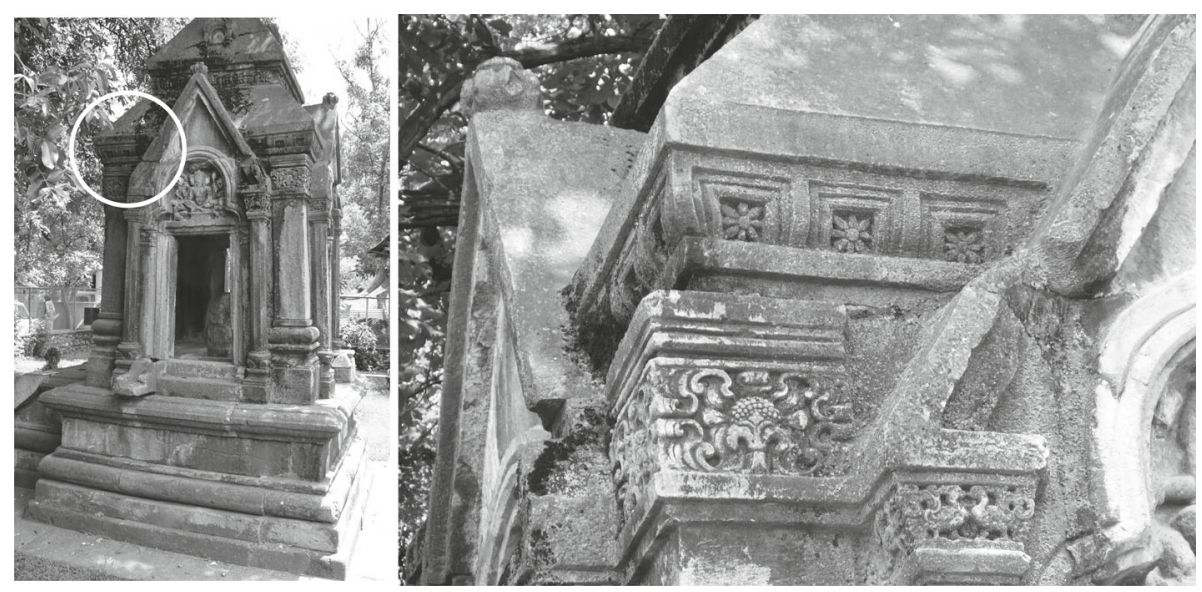

Fig. 8 Earthquake damage to the Payar temple has occurred through lateral displacement of the monolithic roof capstone. At some time in the past nine centuries the roof capstone has shifted $\approx 7 \mathrm{~cm}$ northward, with no damage to the underlying dressed stone blocks. We attribute the drift of the roof monolith to shaking during earthquakes. A close-up of the offset NW corner of the shifted roof stone is shown right, which, in our opinion, Kak (1933) erroneously diagnoses as a failed attempt to dismantle the temple 

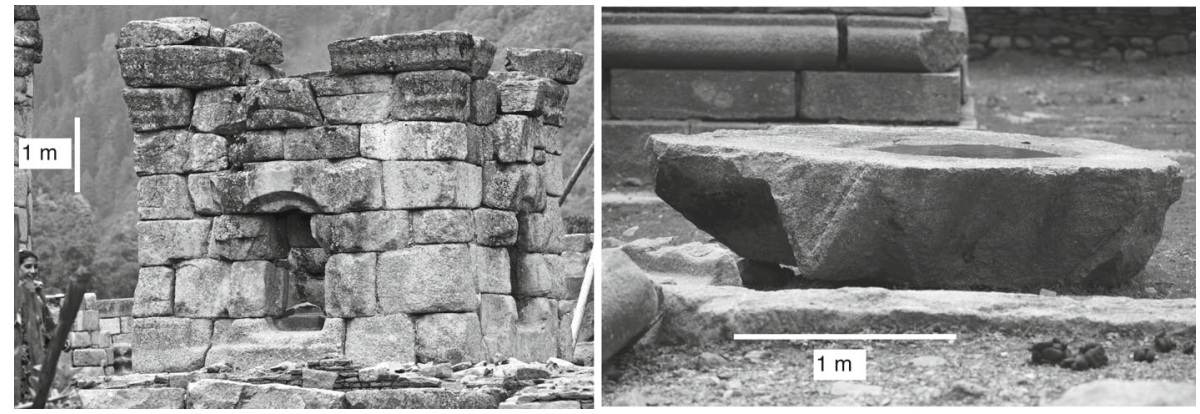

Fig. 9 The upper temple at Naranag and part of its granite roof lies inverted nearby. The monolithic roof measures $2.5 \times 2.5 \times 0.7 \mathrm{~m}^{3}$. Note the absence of a masonry arch, and the assembly of walls from blocks of various dimensions

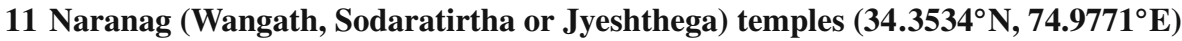

The upper and lower Naranag temples have each shed their monolithic stone roofs. In 2011 the temples were currently being repaired, and there is ample evidence from misplaced ornamentation on those structures currently standing, that the temples have been partly reassembled in earlier times. Although the wall blocks weigh less than several hundred $\mathrm{kg}$ the roofs are much more unwieldy, and the engineering skill to replace the massive roof monoliths has apparently been unavailable during these earlier repairs. The temples are assembled from locally hewn granite blocks (Fig. 9).

\section{Patan's temples (Sankaragaurisvara and Sugandhesa), $\left(34.153^{\circ} \mathrm{N}, \mathbf{7 4 . 5 6 3}^{\circ} \mathrm{E}\right)$}

The 1885 earthquake damaged both of Patan's temples. Damage is described to the Sankaragaurisvara temple by Jones (1885) who reproduces a lithograph from a photograph of the temple taken during his post-seismic investigation of the earthquake (Figs. 10, 11). He fails to indicate specifically what damage occurred, merely implying that the tumbled blocks surrounding the temple had newly fallen. Nor does he mention damage to Sugandhesa, the temple $700 \mathrm{~m}$ to its SE. It is possible that Jones was unaware of Burke's 1868 photographs.
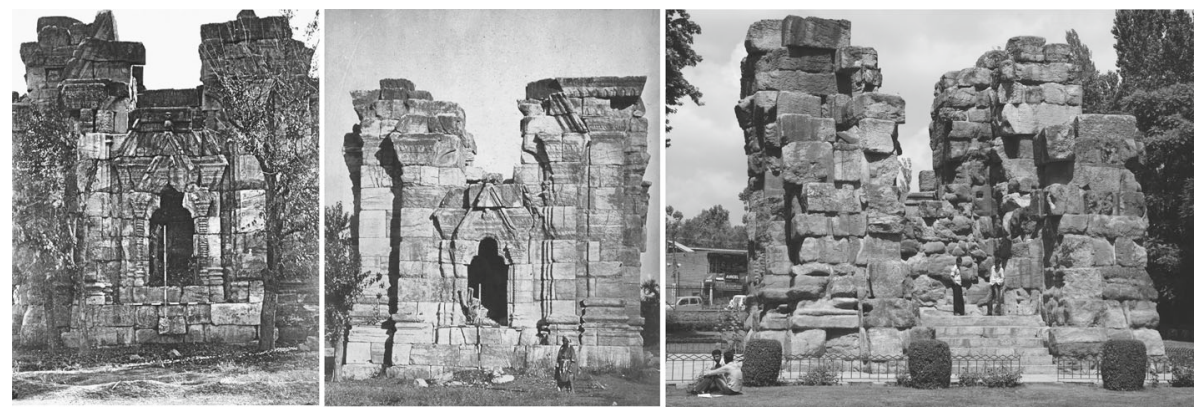

Fig. 10 Views of Sankaragaurisvara taken in 1686 from north and west compared to a 2005 photo from the west. The center view shows a lateral shift in the center trefoil keystone caused by an earthquake prior to 1868 , before its complete loss in the 1885 earthquake (Fig 11). Note the lateral drift of blocks in the left hand corner. Significant corrosion of the limestone blocks has evidently occurred between 1885 and 2005 

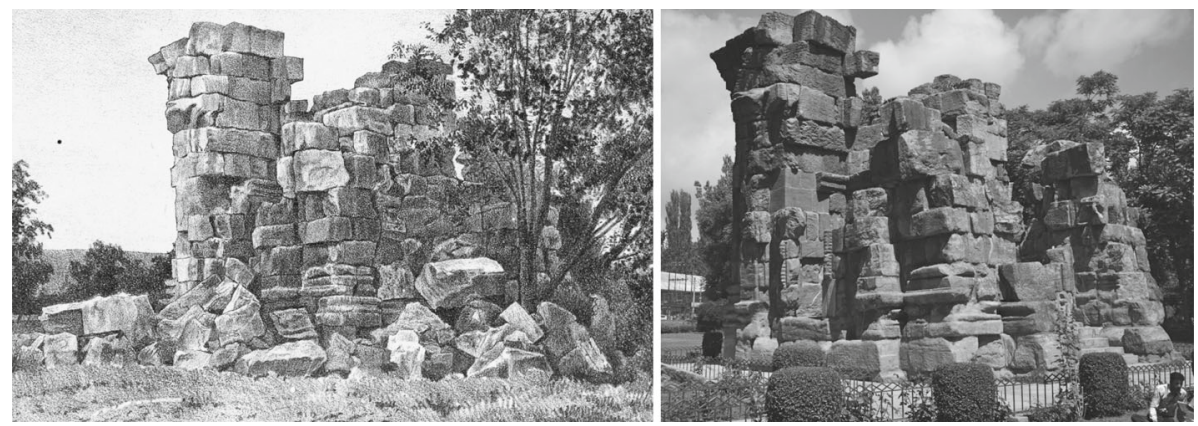

Fig. 11 (Left) Lithograph reproduced from Jones (1885) showing the immediate aftermath of the 1885 earthquake compared to a 2005 photograph from the same angle. (compare with previous Figure). It is possible that Jones took other photos but none were discovered in a search in the Calcutta photographic archives of the Geological Survey of India
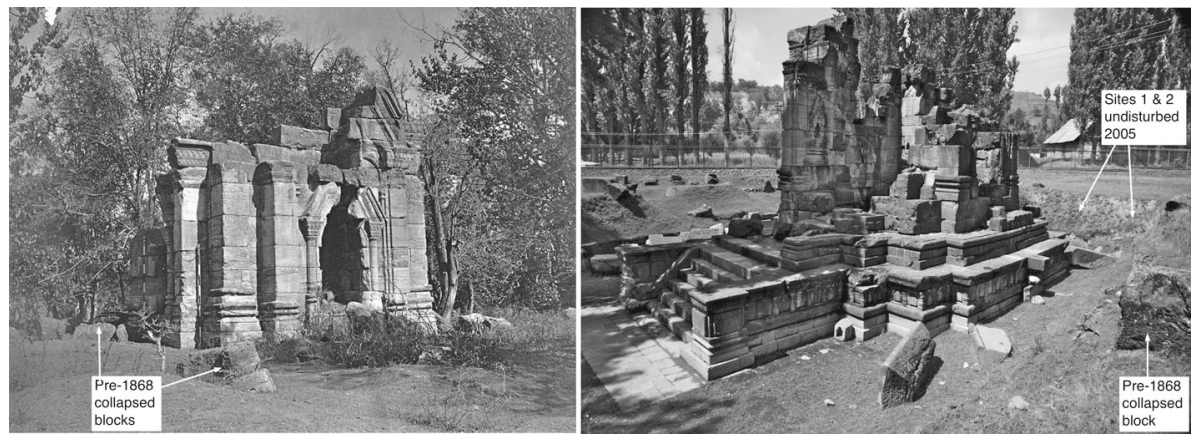

Fig. 12 (Left) View of Sugandhesa by John Burke in 1868 (Cole 1869). Blocks surrounding the temple visible in the foreground lie well above the foundation level and some to the north remain undisturbed in the 2005 photo (right), in contrast to blocks to the east, south and west which have been moved by archaeologists

Comparing the pre-earthquake 1868 temple with the post-earthquake 1885 photos (Fig. 10) the damage to Sankaragaurisvara shows the collapse of the central trefoil portal, and the loss of blocks from the highest parts of the corners of the building.

No corresponding view of Sugandhesa was taken immediately after the 1885 earthquake but the 1868 photograph (Figs. 12 and 13) reveals blocks that must have fallen in a pre-1868 earthquake. These blocks have been toppled long after the accumulation of Kerewa deposits that here exceed $2 \mathrm{~m}$ in thickness (Burbank and Johnson 1983). We show below that the average accumulation rate since $900 \mathrm{AD}$ has been $\approx 2 \mathrm{~mm} /$ year. A rough estimation of their toppling dates can be obtained from their depth of burial, and although Sahni (1918) moved many of these blocks during debris removal, a few remain although we did not excavate them. The 1868 photos of Sugandhesa are compared with present day views in Fig. 13. This reveals two types of damage: tumbled blocks from the summit, and displaced blocks within the edifice.

\section{Sugandhesa $\left(34.1530^{\circ} \mathrm{N}, 7_{4.5622^{\circ}} \mathrm{E}\right)$ : construction and destruction}

We now return to the intriguing question of the date of construction the Patan temples whose blocks could have been ferried across the valley with considerable facility had there been 

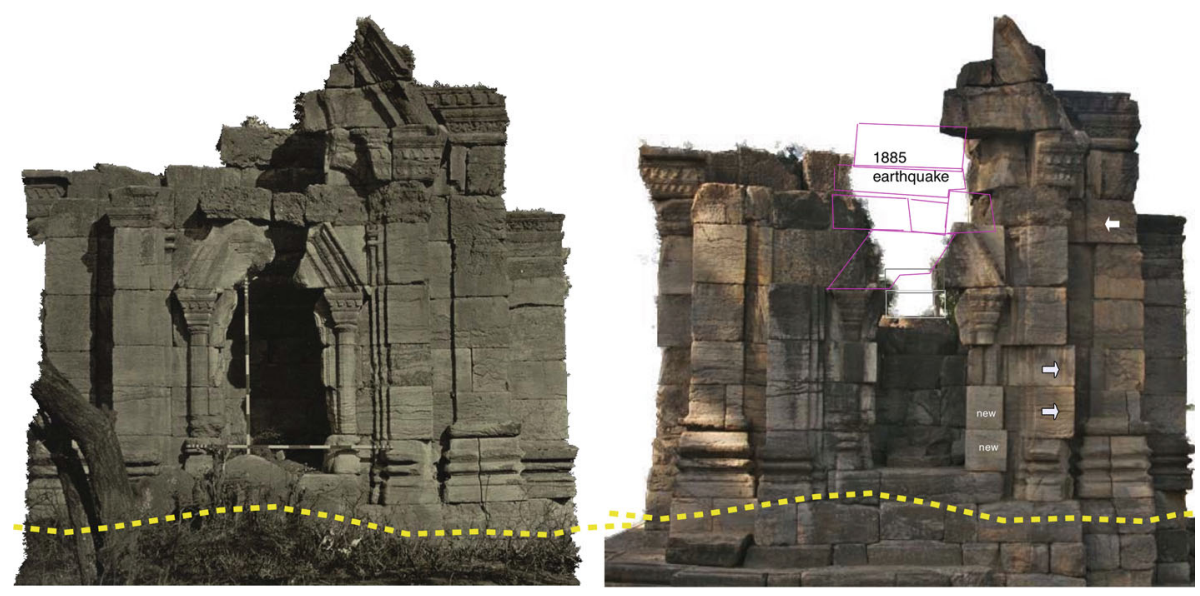

John Burke 1868 Sugandheswara. reproduced in Cole(1869) (British Library Photo 981/1(36))

Sughandesa from south 2011 with missing and displaced blocks
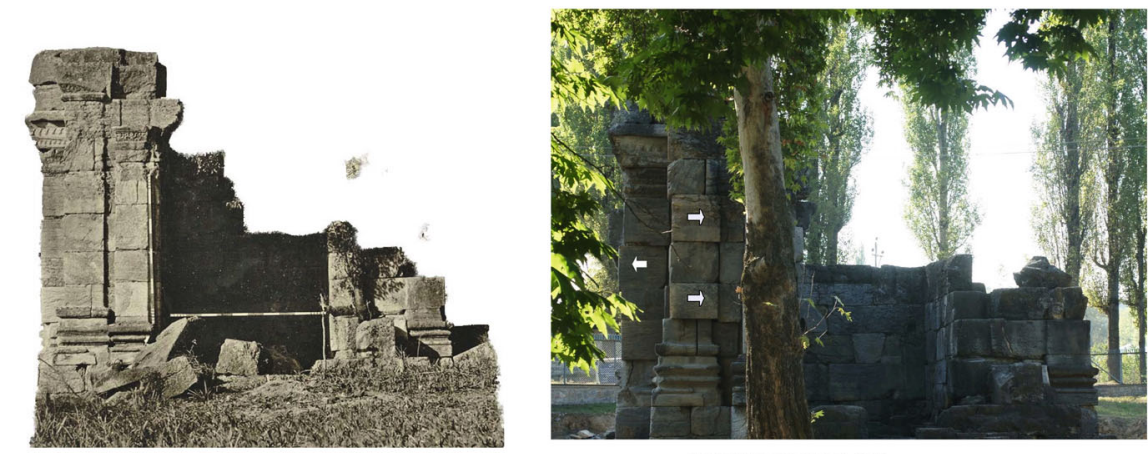

Sughandesa from East 2011

Fig. 13 Views of Sugandhesa: top pair from the south in 1868 (Cole 1869, left) and 2011 (right), and lower pair from the east, showing damage sustained in the 1885 earthquake, and evidence of toppled blocks that we interpret to have fallen in previous earthquakes. Arrows highlight lateral block motions typical of earthquake jostling. The gradation of the poles visible in the left hand figures are in feet

a lake at the time of their transport. In excavating parts of the ruins at Sugandhesa we had two objectives. Our first was to ascertain whether we could establish the time of their construction as occurring before, or after, the draining of the Kashmir flood during the reign of Avantivarman. Our second was to establish a chronology of their destruction, by dating the collapse of temple blocks, assuming that their incremental collapse occurred at the time of former earthquakes in the Kashmir Valley.

We assumed initially that it might be necessary to raise blocks weighing many tons to expose dateable materials. In practice we found it possible to examine layers immediately below assembled foundations, or collapsed blocks, by excavating small inclined pits beneath them. The linear dimensions of our pits in no cases exceeded $30-50 \mathrm{~cm}$, sufficient to establish a local stratigraphy and to retrieve samples suitable for dating, but which left the blocks themselves undisturbed. The pits were refilled immediately after their stratigraphy had been documented.

An opportunity to study the Sugandhesa temple was afforded by the removal in 2010 of debris by the Archaeological Survey of India (ASI), who had exposed several apparently undisturbed blocks near the western edge of the temple. Accordingly, with assistance from 


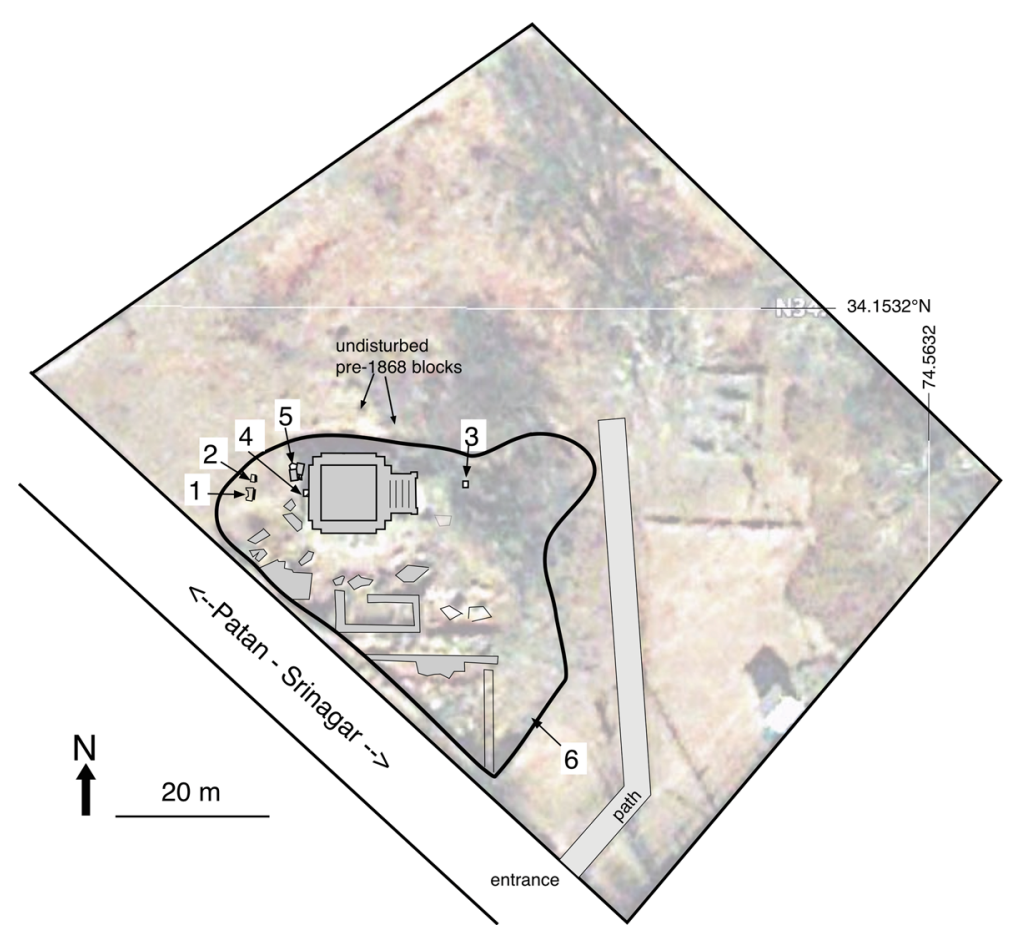

Fig. 14 Map of the Sugandhesa site from a Google Earth image showing the locations of six test pits. The region east and immediately south of the temple was significantly disturbed by Sahni (1918) and the region to the south cleared thoroughly by the ASI in 2010. Perhaps half of the temple complex extends beneath the Baramula/Patan/Srinagar Road. Site numbers correspond to those in text and Fig. 15. Figure 12 shows undisturbed blocks near the surface and the absence of any excavations at Sites 1 and 2 in 2005

the ASI, we undertook a number of minor excavations at the Sugandhesa site in a search for dateable materials. Our excavations were limited to six pits, one of which proved fruitless when we recognized from the exposed strata that they had been disturbed in the past century, or more recently, by archaeologists, and one where we learned little concerning the construction time of the temple. Prior to nineteenth century excavation the site was mantled by a layered deposit of Kerewa silts and clays that had attained a local thickness of $2.7 \mathrm{~m}$. The regular layering of these deposits permitted us to recognize those regions of the site that not been disturbed by archaeologists. The most informative excavations concerning construction and destruction respectively were pits 4 and 5 located within $2 \mathrm{~m}$ of the western edge of the temple (Fig. 14).

Pit 4 provided clues about the time of construction of the site. We excavated $65 \mathrm{~cm}$ below present levels to a stiff brown clay layer $5 \mathrm{~cm}$ below the basal temple foundation block, which yielded a detrital charcoal date of 681-773 AD. Between 20 and $40 \mathrm{~cm}$ depth we encountered a loose, somewhat-porous construction layer of hewn limestone shards with occasional pottery fragments, at the base of we encountered two pottery fragments encapsulating several large charcoal samples (4-8 mm across) that we dated at 775-889 AD (sample 4.5). Within the construction layer we found another sample (4.4) of charcoal with a slightly older date (686$857 \mathrm{AD}$ ), however, the probability density functions of their calendric conversions overlap (Fig. 16). The construction layer is consistent with the historical assembly date for the temple of 883-902 AD. 
Site 5 lies approximately $2 \mathrm{~m}$ to the NNW of this pit and $70 \mathrm{~cm}$ from the edge of the temple. It consists of three blocks that had evidently collapsed on each other- a small basal block measuring 30-60 cm, that we did note excavate, and two larger blocks, one of which we excavated below to date its time of collapse. At its base we found an irregular stone pavement cemented with lime and overlain by a coarse rubble layer with fragments of pottery and equant gravel, significantly less lenticular than the shards in the construction layer observed in pit Site 4. This gravel/rubble layer was found embedded in a matrix of grey colored clay with a sixth century or earlier charcoal date. Less than $5 \mathrm{~cm}$ above this sample, a bright yellow clay layer included a charcoal fragment dated at $1190-1264 \mathrm{AD}$ and $5 \mathrm{~cm}$ above this a charcoal date of 1031-1150 AD was found next to a $15 \mathrm{~cm}$ splintered fragment of this same toppled limestone block. We interpret the observed the strata to indicate that the $2.3 \times 1.2 \times 1.2 \mathrm{~m}^{3}$ block fell circa $1200 \mathrm{AD}$, along with several others, from the west face of the temple into a thin mud layer above the rubble surface, splintering its corner as it did so. A fine clay subsequently formed in a void at the edge of the block indicating a long period of undisturbed sediment accumulation. It is tempting to interpret this clay as associated with ponding since no layering is evident. The clay layer is $17 \mathrm{~cm}$ thick and is surfaced by a darker layer of clay- possibly an ancient soil layer. This is in turn overlain by a $15 \mathrm{~cm}$ layer of clay and rubble leading to the present surface. A small number of present-day tree roots were encountered in the clay layers. Our excavations were insufficient to follow the stratigraphy between these two pits but it seems to us unlikely that the two gravel layers that we encountered were contiguous.

Approximately $10 \mathrm{~m}$ to the west of the temple foundation a rough stone pavement with lime-mortar had been exposed by the ASI, similar to that found beneath the large tumbled block at Site 5, but at a shallower level. We searched for dateable materials under two large limestone blocks above this surface. Block 1 is a sculptured trefoil arch monolith and measures about $2.5 \times 1 \times 1 \mathrm{~m}^{3}$ and is tilted at about $60^{\circ}$ to the east with its lower edge resting on a thin layer of soil above the rubble-stone floor. There was no evidence of a

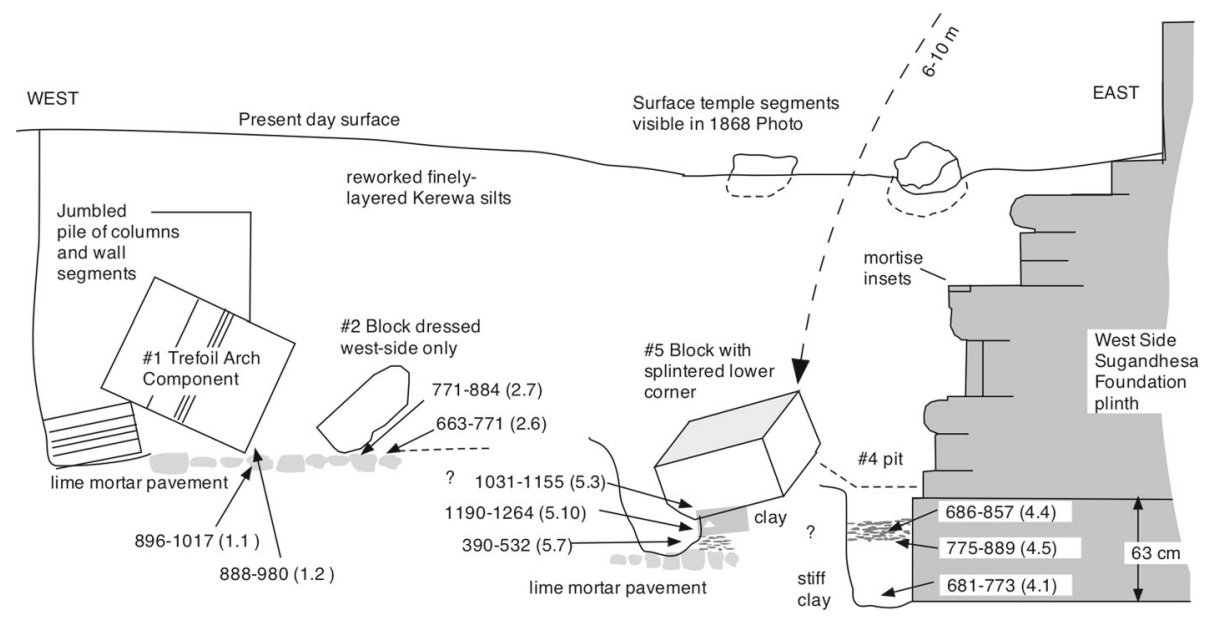

Fig. 15 Schematic section through excavations at west end of the Sugandhesa Temple with CE dates. A construction layer contiguous with the foundation confirms that temple construction was initiated before $890 \mathrm{AD}$. Less than $70 \mathrm{~cm}$ west of the temple a splintered block (with its spalled fragment nearby) collapsed on an ancient rubble layer and was flooded by a fine clay layer dated at approximately c.1200 AD. It is possible that block 1 and 2 were awaiting assembly prior to abandonment of temple construction. Although both blocks were exhumed only after 2005 (see Fig. 12 right) we found them exposed by the ASI in 2010 with no dateable materials above them. Accelerator mass spectrometer date conversions are listed in Table 1 
construction layer of chips at this site. Sample 1.2 (888-980 AD) was found in a soil/clay layer between the megablock and the stone floor and, sample 1.1 (896-1017 AD) from just below the pavement. Block 2 was a smaller block roughly one quarter the size of Block 1 , but was dressed only on its upper west-tilted surface. Its lower surface appears to have been supported by another block at some time because fluvial sedimentary layers now underlie the block with a conformable graded bedding deposit, suggesting infilling of a void. Two detrital charcoal samples here (2.6 and 2.7) indicated dates of 663-771 and 771-884 AD.

In what appears to be rubbish pit near Site 6 (Fig. 14) we retrieved a $0.5 \mathrm{~kg}$ sample of spongy iron ore (pp. 50-53 Stansbie 1908) with the following principle components (Fe 59\%,Ca $6.6 \%$, Si $6.3 \%, \mathrm{~K} 1.7 \%$, Al 1.1\%, Mg 0.7\%). We assume that this material may have been destined for fabricating the clamps used in temple construction, although as noted above, the mortise locations on the west face of Sugandhesa facing outwards (Fig. 15) suggests that this stone was reworked from elsewhere. Though now clean, Kak (1933) mentions that traces of rust were evident in these joints when he visited the temple in the 1930s.

\section{Interpretation of detrital charcoal dates from Sugandhesa}

The internment of detrital charcoal samples can follow their formation by many years, and hence the latest possible calendric dates are usually the most reliable indicators of the age of subsurface strata. However, the collapse of buildings often leaves voids that may be slowly filled after their collapse, incorporating post-collapse detrital carbon, and raising additional difficulties in dating the precise moment when temple blocks were tumbled. Ideally we had hoped to find seeds or insects trapped at the point of impact of limestone blocks and the underlying surface but in practice our charcoal samples could all be inherited from years before, or after, block collapse.

Probably the least ambiguous interpretation comes from sample 4.5, which consisted of several large charcoal fragments sandwiched between two concave shards of pottery, suggesting a contemporaneous non-detrital origin. This date unfortunately coincides with a triplication in the radiometric/calendric conversion which increases the radiometric uncertainty of \pm 20 years to a $95.4 \%$ calendric confidence interval of more than a century (775-889AD). Although this range permits temple construction to have started long before Samkaravarman's reign, it does provide a definitive confirmation that construction of the temple was initiated before the end of his reign.

Bayesian analysis of the ensemble of age determinations between 670 and $900 \mathrm{AD}$ appears to us unwarranted given the uncertainties attending assumptions about the source of the numerous detrital samples we are dating. We note that the cluster of dates from $\approx 700$ to $900 \mathrm{AD}$ (Fig. 16) is consistent with the incorporation of surface detrital charcoal that may have been blowing around the site for almost 200 years before and during temple construction.

The eleventh and thirteenth century probable date distributions in Fig. 16 (5.3 and 5.10) are confined to a clay that developed after the collapse of block 5 from the west face of the temple onto a surface of considerably older age. A possible earthquake is mentioned briefly by Kalhana but is not mentioned in other histories, which could be responsible for this damage. "1123 AD: The orb of the day blazed fiercely, the earth trembled frequently and disastrous cyclones blew which brought down trees and boulders" (Book 8, Verse 1167; Stein 1898). These later dates do not correspond to known periods of willful desecration. For example, it is believed that Mahmud of Ghazni was repulsed outside the valley and prevented from invading the Kashmir Valley 1015-1021, and Muslim rule slowly developed only after 


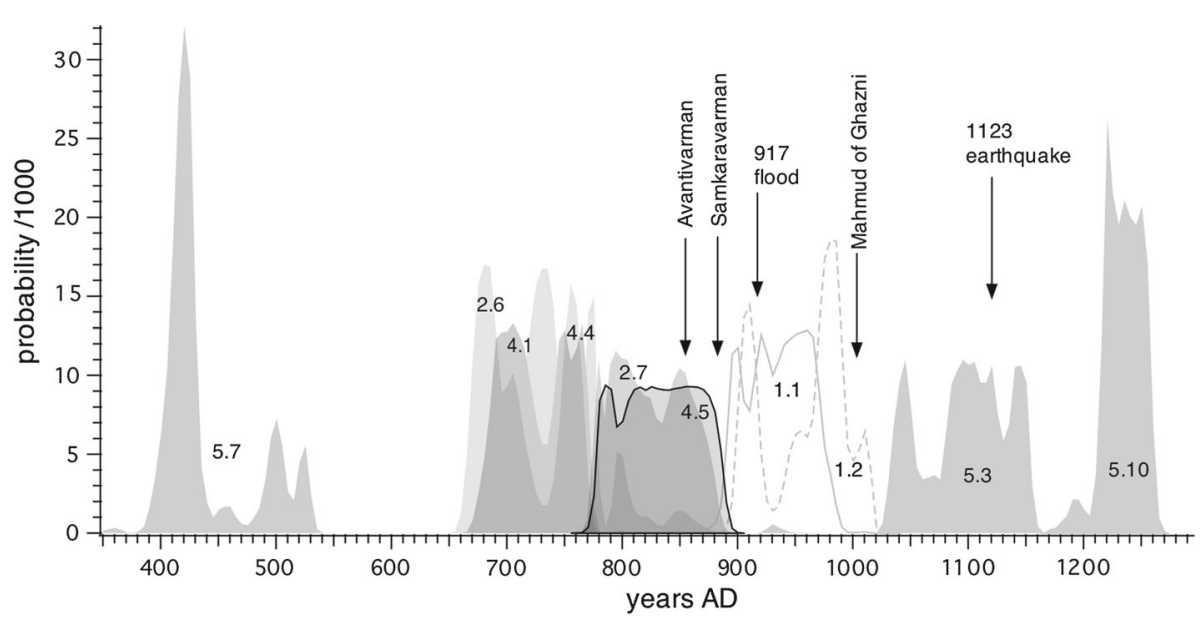

Fig. 16 Probability distributions from calendric date conversions of ten C14 samples from layers beneath temple blocks on the west side of Sugandhesa Temple (Table 1; Fig. 15). The central cluster of detrital C14 dates are consistent with a construction start for the temple corresponding to the reign of Samkaravarman, but the temple site may have been occupied 400 years earlier

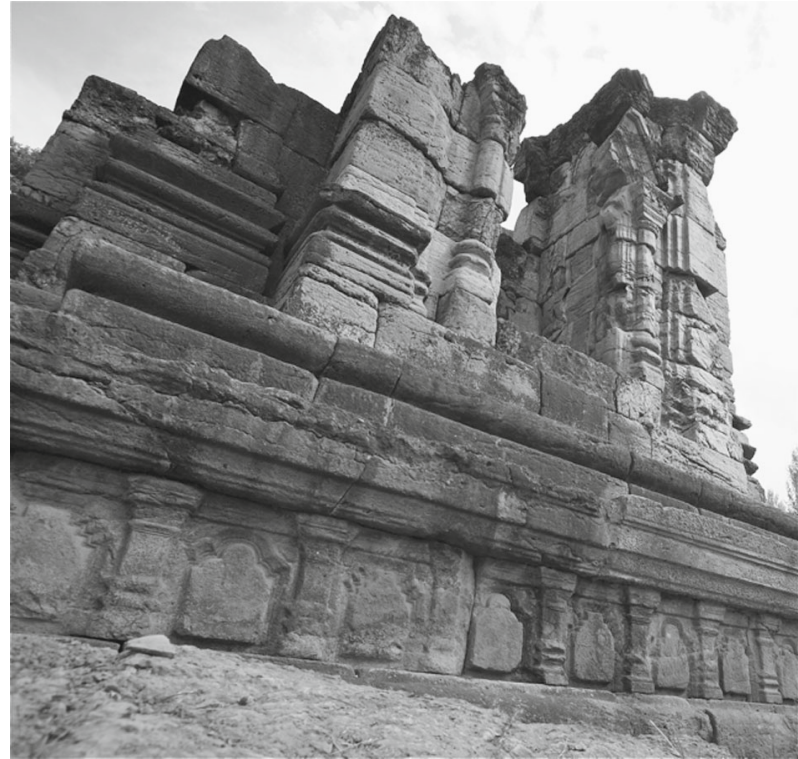

Fig. 17 View from Block 5 (lower foreground) upwards showing west face of the Sugandhesa ruin (much foreshortened by the wide angle lens used in this view). The height of the pillar right is $\approx 8 \mathrm{~m}$, and block 5 is believed to have been thrown $0.7 \mathrm{~m}$ clear of the ruin from the central pillar, without impacting the lower structure. Note lateral displacement of upper blocks within the columns caused by shaking, and unfinished decoration in the frieze surrounding the basal pedestal. The top surface of this pedestal includes depressions mortised for iron clamps which Kak (1933) noted contained traces of rust. We exposed an iron ingot from Site 6 similar to others that may have been destined to fasten parts of the Sughandesa ruin now hidden from sight 
1340. The fanatical Sikander the Iconoclast is believed to have damaged many temples in Kashmir 1389-1414, a century after the deposition of the layer dated by samples 5.10 and 5.3.

The tumble of ruins to the west of the temple are too far from the Sugandhesa ruin to have collapsed from its edifice. We consider there to be two explanations for these blocks. The first is that they are the ruins of a temple structure to the west of Sugandhesa that lies mostly under the road, and the second is that the blocks were stones awaiting assembly. That is, the blocks may be the remnants of a former construction site. Block 1 is a large $(2 \mathrm{~m} \times 1 \mathrm{~m} \times$ $0.8 \mathrm{~m}$ ) dressed stone block that lies inclined on a lime mortar floor that appears to post-date temple construction by 50-120 years (Samples 1.1 and 1.2, Fig. 16), whereas block 2 appears to be synchronous with temple construction. Both these blocks may have been undergoing preparation for assembly in the Sugandhesa structure, but a shortage of funds caused by the death of Avantivarman in 902, and his queen in 915, led to construction being abandoned. We qualify this interpretation with the observation that from the continuity of the Kerewa deposit sediment layering we can be reasonably certain that Block 2 has lain undisturbed for the past ten centuries, but it is possible that Block 1 may have fallen from the structure at the same time and close to Block 5, but may have been moved west of the temple by engineers deputed to repair the temple in the tenth century, or possibly by Sahni (1918) during his extensive disturbance to the site in the twentieth century. We consider the latter unlikely because the surface above the blocks was apparently intact in our 2005 photograph. The definitive proof of the date of emplacement of both blocks would have been possible if ASI excavations the previous year had not removed dateable deposits immediately overlying the two blocks we investigated.

The collapse of Block 5 and others from the west side of the temple has occurred without significant damage to the temple plinth (Fig. 17). These were heavy stones that fell from a considerable height $(>7 \mathrm{~m})$, and had they impacted the structure during their descent there is little doubt they would have splintered the cornice or other layers. In principle this permits estimates of their minimum initial velocities.

\section{Discussion}

Visitors to Kashmir may justifiably conclude, from the striking flatness of the valley floor as they fly into the valley, or view it from mountainsides, that the valley resembles the floor of a former lake. The conclusion is countered by the observation from geologists that many of the valley floor sediments are not lacustrine but sub-aerial (e.g. Burbank and Johnson 1983), however, the lower levels bordering the Jhelum are undoubtably flood deposits. The present article focusses on a ninth century flood described in part mythical terms in ancient histories of Kashmir. It is thus perhaps surprising that we can demonstrate quantitatively the conditions under which the ninth century flood may have developed, how deep it had to be and its minimum volume (Figs. 2, 3), and how long it would take to form a transient lake in the valley (Fig. 3). The ease with which $30 \%$ of the valley floor can be submerged by a $25 \mathrm{~m}$-high natural dam downstream from Baramula suggests that this may have occurred many times in Kashmir's prehistory. Flooding of the valley is consistent with one other historical flood c. $1250 \mathrm{BC}$ that is supposed to have submerged a city near the present Wular Lake, and with an even older legend linked to the very foundation of the Kingdom of Kashmir (c.3000 BC). Given that floods formed an important part of Kashmir's history we suggest that a transient lake may have facilitated the transport of temple blocks to parts of the Kashmir Valley during the period of Buddhist and Medieval Hindu temple building. 
Table 1 Radiocarbon results and calendar age estimates for samples obtained from the Sugandhesa Temple site

\begin{tabular}{|c|c|c|c|c|c|c|}
\hline CURL\# & Site & $\mathrm{mg} \mathrm{C}$ & 14C year & $\mathrm{BP}$ & From $\mathrm{AD}$ & To AD \\
\hline 14010 charcoal & 1.1 & 0.57 & 1,080 & \pm 20 & 896 & 1017 \\
\hline 13512 charcoal & 1.2 & 0.63 & 1,120 & \pm 20 & 888 & 980 \\
\hline 14075 mullusc & 2.5 & 0.41 & 17,275 & \pm 50 & & \\
\hline 13522 charcoal & 2.6 & 0.34 & 1,300 & \pm 20 & 663 & 771 \\
\hline 14019 charcoal & 2.7 & 0.47 & 1,210 & \pm 15 & 771 & 884 \\
\hline 14964 charcoal & 4.1 & 0.67 & 1,275 & \pm 15 & 681 & 773 \\
\hline 14984 charcoal & 4.4 & 0.56 & 1,245 & \pm 15 & 686 & 857 \\
\hline 14961 charcoal & 4.5 & 0.50 & 1,195 & \pm 20 & 775 & 889 \\
\hline 14960 charcoal & 5.1 & 0.55 & 815 & \pm 15 & 1190 & 1264 \\
\hline 14980 charcoal & 5.3 & 0.61 & 940 & \pm 15 & 1031 & 1155 \\
\hline 14985 charcoal & 5.7 & 0.59 & 1,625 & \pm 15 & 390 & 532 \\
\hline
\end{tabular}

Upper and lower 2-sigma limits (95.4\% confidence interval) of the estimated calendar age solution (AD), from OxCal 4.2 (Bronk Ramsey 2009). The complete probability distributions representing the normalized calendar age solutions for each charcoal sample are given in Fig. 16. CURL numbers are University of Colorado Laboratory for Radiocarbon Preparation and Research accession numbers

The foregoing investigation of the Sugandhesa temple ruin has established (with $95 \%$ confidence) that construction was started before 889 AD (Sample 4.5, Table 1), and we may deduce from historical texts that construction probably terminated by the time of the demise of Samkaravarman in 902 AD, if not by 915 AD, the time of the execution of Queen Sughanda, after whom the temple is named. The 230 year scatter of dates in detrital samples prior to $883 \mathrm{AD}$ (Fig. 16), when construction is historically supposed to have commenced, is typical of the incorporation of detrital fragments formed over previous decades into later layers. The two century spread in dates means that we are unable to answer the important question of when the Sugandhesa temple blocks were transported to the point where they were being assembled. The traditional interpretation is that they were transported from the plateau of Parihasapura starting in $883 \mathrm{AD}$ when Samkaravarman assumed power. The scatter in dates permits them to have been barged in as early as $855 \mathrm{AD}$ when we infer the lake to have been flooded, but does not require it. The pile of miscellaneous building materials exposed by the ASI in 2010 to the west of the temple (and extending currently undisturbed beneath the Baramula/Srinagar road) could be consistent with this being either the ruin of an earlier temple or a resource of partly sculpted blocks awaiting shaping and incorporation into the Sughandesa edifice.

We examined only one toppled stone unequivocally symptomatic of earthquake damage, and its collapse is consistent with it falling during the 1123 earthquake described briefly by Kalhana (Book 8:1167; Stein 1898). The date of its fall is bracketed by a stone pavement (presumably at the surface in $902 \mathrm{AD}$ ) and a clay layer that infilled a void after its collapse 200 years later, and hence the date of its fall is much less precise than we would have liked. Further study of this and other blocks is possible since our investigation of the site was not extensive.

The date of partial collapse of the Sankaragaurisvara and Sugandhesa temples in the earthquake of 1885 is historically recorded by Jones (1885), but the date of collapse of earlier blocks visible in the 1868 photos is not known. Numerous strong earthquakes are recorded to have occurred in the valley in the preceding 400 years, most notably in $1501,1555,1669,1736$, 1779 and 1828 (Table 2). If we assume that the surface blocks visible in the 1868 photographs 
Table 2 Earthquakes in Kashmir summarized by (1) Iyengar et al. (1999); (2) Bashir et al. (2009); (3) Bilham et al. (2010); (4) Tarikh-i-Hassan (1896); (5) Hough et al. (2009)

\begin{tabular}{|c|c|}
\hline Year & Comments \\
\hline $1250 \mathrm{BC}$ date uncertain & $\begin{array}{l}\text { A devastating earthquake struck at night. The entire town was reduced to } \\
\text { shambles. Cracks appeared on the surface at earth, and from there water } \\
\text { gushed out and the entire town was deluged. Thus in the aforesaid } \\
\text { manner there appeared Wular Lake }(1,4)\end{array}$ \\
\hline 883 & Uncertain date, no damage described, as discussed in the present article $(1,4)$ \\
\hline \multirow[t]{2}{*}{1123} & Kalhana 1123 AD: Book VIII, Verse $1167(1,2,4)$ \\
\hline & Stein 1898 "earthquakes occurred repeatedly" page 418 \\
\hline 24 Sept 1501 & 3 months of aftershocks $(1,2)$ \\
\hline 1552 & Not an earthquake (3) \\
\hline Sept. 1555 & $\begin{array}{l}\text { Earthquakes continued for several days. Landslides and liquefaction. Several } \\
\text { accounts, some assign date as } 1554(1-5)\end{array}$ \\
\hline c. $1560 / 61$ & No details (2) \\
\hline $1569-1577$ & No details (2) \\
\hline 23 June 1669 & The buildings rocked like cradles. No loss of life. (2) \\
\hline c. $1678 / 79$ & Persistent shaking. Reconstruction needed (2) \\
\hline 1683 & No details (2) \\
\hline 24 March 1736 & $\begin{array}{l}\text { Earthquakes for } 3 \text { months. Buildings of the city and hamlets razed to the } \\
\text { ground ( } 2 \text {. list as 1735) }\end{array}$ \\
\hline 1779 & $\begin{array}{l}\text { Srinagar and hamlets flattened and aftershocks for } 14 \text { days. People took shel- } \\
\text { ter in the open. Bashir et al. (2009) list event as 1778; Oldham (1883) as } \\
1780\end{array}$ \\
\hline c. $1784 / 85$ & People thrown. Shocks persisted 6 months \\
\hline 1803 & Earth ripped apart, houses collapsed, people buried under walls (2) \\
\hline 26 June 1828 & Vigne (1844) 1,200 houses collapsed, 15 days of aftershocks \\
\hline 1863 & (2) Lawrence (1895) indicates 1864 \\
\hline 30 May 1885 & Jones $(1885) 6.2<\mathrm{Mw}<6.3$ (Ambraseys and Douglas 2004) \\
\hline 8 Oct 2005 & $\mathrm{Mw}=7.6$ Instrumental period. One week of strong aftershocks \\
\hline
\end{tabular}

With the exception of the 1885 and 2005 earthquakes, no magnitudes can be assigned to these earthquakes

(Figs. 12 and 13) were buried 40-50 cm with just their top 20-30 $\mathrm{cm}$ protruding, we might infer, from the mean Kerewa sediment accumulation rate of 2-3 mm/year since 900 AD, that they fell 200 years prior to 1868 , possibly at the time of earthquakes in 1669 or 1736 . Collapse in the 1555 earthquake is not consistent with the evidence available to this study.

The brevity of our Sugandhesa site-study means that our investigations though promising, must be considered preliminary in nature. Our study was restricted to the western edge of the temple. Most of the site to the west, south and east of Sugandhesa has been disturbed by archaeologists in the past 200 years, who have unwittingly destroyed the evidence we seek. Ironically, although these earlier archaeologists have shifted more than ten metric tons of temple blocks, our study is based on fewer than $6 \mathrm{mg}$ of charcoal! Fortunately the northern edge of the temple has not been disturbed, except close to the foundations, and extensive undisturbed ruins remain beneath the road, where future seismologists may be able to resolve some of the questions we raise about the incremental collapse of the temple.

The northern edge of the valley is effectively being drowned by the sediments of the Jhelum, as the SE side of the valley rises due to tectonic processes (Burbank and Johnson 1983). The relative elevation changes amount to $\approx 3 \mathrm{~mm} /$ year over the Cenozoic period, which suggests that early temples on the northern side of the valley may have been buried 
by up to $3.6 \mathrm{~m}$ of river sediments since their construction. This slow tilt down to the NW has raised the water table at the temple sites on the NE side of the valley (e.g. Pandrethan, Fig. 7), which is responsible for the now discredited inference by Cunningham (1848) that flooded temple compounds owe their origin to the worship of Naga. This was refuted by Marshall (1907) who noted that a flooded courtyard was incompatible with the provision of large stone tanks in the courtyard to hold water for temple ablutions. It is possible that some of the many temples mentioned in the Rajatarangini whose locations have now been lost, may in the future be discovered beneath sediments accumulated in the past millennium, and that the methods we outline here can be applied to their excavation.

A final remark concerns the ease with which a relatively minor blockage ( $<25 \mathrm{~m}$ high) of the Jhelum near Baramula in the ninth century resulted in a flood in the Kashmir Valley. It is impossible to believe that this was an isolated instance of such an event in the history of Kashmir, or that previous and future landslides could not be similar or higher than the one that was breached by Suyya. The Rajatarangini describes the mythical origins of Kashmir (c.3000 BC) as being associated with a flood that once occupied the valley that was cleared by the gods, creating "the land known by the name Kashmir in the space previously occupied by the lake" Book 1 Verse 27. Iyengar et al. (1999) reproduce an entry from the Tarikh-i-Hassan (Table 1) about the earthquake c.1250 BC (Table 1) that submerged a town near the current location of Wular Lake and which simultaneously submerged the region from Khadanyar to Bij Behara - the same locations as those associated with the Suyya legend. Geologically, the presence of a narrow gorge flanked by unstable mountainsides, and shaken by occasionally earthquakes, means that landslides must be considered a constant threat. Presumably a record of these floods has been interred in the valley floor awaiting geological study.

\section{Conclusions}

We investigated the details of the Suyya legend described in Kalhana's Rajatarangini in an attempt to establish the timing of an earthquake that is inferred to have triggered a landslide in the gorge of the Jhelum where it exits from the Kashmir Valley. We first conclude that the earthquake described in the Tarikh-i-Hassan, if it occurred in $883 \mathrm{AD}$, cannot have triggered the landslide and flood that is inferred to have been drained by Avantivarman's engineer Suyya. The flooding and drainage of the valley requires at least 2 years in normal discharge conditions, and Avantivarman died in the third month of 883 AD following a time of typically low winter discharge rates. We conclude that Avantivarman inherited a flood at, or soon after, the time he ascended the throne in $855 \mathrm{AD}$. That Kalhana indicates the exorbitant price of rice in administrations immediately prior to Avantivarman's reign suggests that the flood may already have existed early in his reign. We infer that the flood was drained early in Avantivarman's rule, which resulted in a much expanded, irrigated farm area, and the price of rice falling during his reign to unprecedented low values.

We are unable to determine whether the $883 \mathrm{AD}$ landslide and earthquake described in Tarikh-i-Hassan is independent from the Rajatarangini flood clearance account described by Kalhana. We suspect that the 883 AD date cited by Pir Ghulam Hassan Khuihami may be an error, and that he is describing the same event as Kalhana (Stein 1898). We have not investigated the date of the landslide, although in principle this may be determined from a study of the landslide detritus in the Jhelum valley. Similarly we have not investigated specifically the dates of flood deposits in the valley.

Many of the Kashmir's temples are constructed close to the shores of the transient ninth century flood, a lake that would have facilitated the movement of the megablocks used in 
temple construction. The existence of a lake during the early part of Avantivarman's rule would have aided the construction of temples by him in Avantipur, although these temples are already close to the river Jhelum. In contrast, the two temples at Patan lie far from the Jhelum or other canals. This led us to initiate a pilot study of the date of construction of the temples at Patan, whose construction, according to historical texts would have post-dated the drainage of the inferred pre-883 AD lake.

A pilot excavation of the Sugandhesa temple yielded several detrital charcoal samples that we used to constrain various events in its construction and destruction. We confirmed with $95 \%$ confidence that its construction had started at the latest by $889 \mathrm{AD}$, a confirmation of historical accounts of its construction dates (883-902 AD), but estimates of its earliest time of construction were not possible due to intrinsic ambiguities in the conversion of the radiometric year 1192 BP to calendric years, and additional uncertainties in the contemporeneity of charcoal samples and events in the temple complex. Our data are unable, in particular, to establish a time when temple blocks from Buddhist Parihasapura were moved to Patan for construction purposes. The detrital charcoal dates are consistent with a pre- 855 transfer of building materials, but do not require it. Hence our speculation that temple construction was facilitated by barging megablocks to sites within the Kashmir Valley remains unsubstantiated.

Archaeologists (Sahni 1918; Kak 1933) have conjectured that Sugandhesa was abandoned before completion. Ornamentation surrounding the pedestal remains unfinished, and parts of the edifice include structural components from former temples that may have been ultimately destined for erasure or repair. In support of this observation we note the remarkable pile of building materials to the west of the temple include blocks that may have been in the process of being prepared for incorporation into the structure before the site was abandoned.

Several examples of the mode of collapse and damage to Kashmir's temples are described that we ascribe to earthquake shaking. The most telling is the lateral displacement of blocks within walls, that cannot be the result of vandalism. The collapse of blocks from the temple edifice onto dateable materials in floors or soils, potentially provides the time of former earthquakes, and we demonstrate the feasibility of the method. We caution, though that if the date of its fall is to be bracketed precisely, the careful exhumation of the stratigraphy surrounding each block, above and below is vital. We have provisionally associated partial collapse of the Sugandhesa edifice in Medieval times to a historical earthquake that occurred in $1132 \mathrm{AD}$ (Table 2). Where age bracketing by materials above and below a block internment event is unavailable, we recognize that the age of the impact surface may be insufficient to date a shaking event. Two large blocks in Sugandhesa that had been exposed by undocumented archaeological excavations in 2010 fall into this category. We also note that an approximate date for collapsed blocks is available from the depth of burial of partly buried surface blocks, where the sedimentation rate is known and uniform with time. Applying this method to 1868 photographs of Sugandhesa we speculate that a seventeenth century earthquake may have damaged the temple, prior to the historically described damage that occurred in 1885 . We find no evidence for collapse during the 1555 earthquake, hitherto considered the largest of Kashmir's historically recorded earthquakes.

We conclude with the observation that many of Kashmir's temples have been disturbed by archaeologists who have moved temple blocks without realizing the wealth of information contained in the soil and clay layers contiguous with these blocks. Inspection visits to the wellknown temples at Martand, Avantipur, Naranag and elsewhere indicate that archaeologists in the past 100 years have left no surface stones undisturbed-destroying all possibility of the kind of investigation described here. The currently unexcavated layers north of the Sugandhesa temple thus offer an almost unique opportunity to establish an earthquake chronology for the Kashmir Valley. 
Acknowledgments This research article is dedicated to the memory of Nicholas Ambraseys, who died 29 Dec 2012 leaving the world a five-decade-long legacy of studies of historical earthquakes, landslides and engineering. As recently as February 2012 he published an article on a similar sequence of events to that described here-the great Usoi/Sarez, Pamir earthquake, landslide and flood of 1911. The Usoi dam has a crest height of $650 \mathrm{~m}$, an order of magnitude higher than the inferred height of the Khadanyar landslide discussed here, and Lake Sarez which was impounded by the Usoi dam, took more than a decade to fill, and remains a threat to downstream populations a century after the earthquake. He expressed a keen interest in the unique earthquake, landslide and flood hazards of the Kashmir Valley, and in the last year of his life was eager to learn the results of our investigations. We thank the Director General of the Archaeological Survey of India for permission to study the Sugandhesa Temple, and Prakash Kumar and Fayaz Ahmad Shah for their generous assistance in our field work. Shabir Ahmad prepared a site map in September 2011. The C-14 AMS sample preparation and subsequent dating was supervised by Scott Lehman (INSTAAR, Boulder, Colorado) who provided invaluable advice on sampling methods. We thank John Drexler for the elemental and mineral analysis and electron microscope work on the iron slag sample 6.1. We thank an anonymous reviewer for numerous helpful suggestions that have clarified the text. The study was funded by National Science Foundation grant EAR 0739081.

Open Access This article is distributed under the terms of the Creative Commons Attribution License which permits any use, distribution, and reproduction in any medium, provided the original author(s) and the source are credited.

\section{References}

Ambraseys N, Bilham R (2012) The Sarez-Pamir earthquake and landslide of 18 February 1911. Seismol Res Lett 83(2):294-314. doi:10.1785/gssrl.83.2.294

Ambraseys NN, Douglas J (2004) Magnitude calibration of north Indian Earthquakes. Geophys J Int 159:165206

Bates CE (1873) A Gazeteer of Kashmir and adjacent districts of Kishtwar, Barawar, Jammu, Naoshera. Punch and the Valley of Kishenganga. Superintendent Govt. Printing, Calcutta, p 560

Bashir A, Bhat MI, Bali BS (2009) Historical record of earthquakes in the Kashmir valley. J Himal Geol 30(1):75-84

Bilham R, Singh B, Bhat I, Hough S (2010) Historical earthquakes in Srinagar, Kashmir: clues from the Shiva temple at Pandrethan, GSA special paper 471 on ancient earthquakes, (edited by Manuel Sintubin, Iain S. Stewart, Tina M. Niemi, and Erhan Altunel. ISBN 9780813724713

Burke J (1868) British library. Shelfmark: Photo 981/1(40)

Burbank DW, Johnson GD (1983) The late Cenozoic chronologic and stratigraphic development of the Kashmir intermontain basin, northwestern Himalaya. Palaeogeogr Palaeoclim Palaeoecol 43:205-235

Cole HH (1869) Illustrations of ancient buildings in Kashmir, India Museum. Published by India museum, W. H. Allen and co., publishers to the India office

Cunningham A (1848) An essay on the Arian order of architecture, as exhibited in the Temples of Kashmir. J Asiatic Soc Bengal, 241-327

Dunning SA, Mitchell WA, Rosser NJ, Petley DN (2007) The Hattian Bala rock avalanche and associated landslides triggered by the Kashmir earthquake of 8 October 2005. Eng Geol 93:130-144

Hough SE, Bilham R, Bhat I (2009) Kashmir Valley megaearthquakes. Am Sci 97(1):42-49

Iyengar RN, Sharma D (1996) Some earthquakes of Kashmir from historical sources. Curr Sci 71(4):300-331

Iyengar RN, Sharma D (1998) Earthquake history of India in medieval times. Central Building Research Institute, Roorkee 247-667, p 124

Iyengar RN, Sharma D, Siddiqui JM (1999) Earthquake history of India in medieval times. Indian J Hist Sci 34(3):181-237

Jones EJ (1885) Report on the Kashmir earthquake of 30 May 1885. Rec Geol Surv India 18(4):221-227

Kak RC (1933) Ancient monuments of Kashmir. India Society, 172 pp 1971, Reprint

Lawrence WR (1895) The Valley of Kashmir. Henry Froude, London, p 478

Marshall J (1907) Annual report of the archaeological survey of India 1906-1907, Calcutta, p 179

Montgomerie TG (1858) Map of Kashmir, with part of adjacent Mountains, surveyed on the basis of the great trigonometrical survey of India, under the instruction of Lieut.-Colonel A. S. Waugh, Engineers, F.R.S., F.R.G.S., Surveyor-General of India; by Capt. T. G. Montgomerie, Engineers, F.R.G.S., 1st Assistant G. T. Survey of India, and the assistants under his orders, during 1855, '56, and '57. Scale, 2 miles to 1 inch. With an insertion entitled, Kashmir Route Map; scale, 32 miles to 1 inch; on 4 sheets; size, 50 inches by 50 inches 
Montgomerie TG (1886) 1/4" Map of Kashmir, Scale 4 miles to the inch. (14.6 Mb)

Oldham T (1883) A catalogue of Indian earthquakes from the earliest times to the end of AD 1869. Mem Geol Surv India 19(1):163-215

Prinsep J (1858) Essays on Indian Antiquities, Historic, Numismatic, and Palæographic, of the Late James Prinsep: to which are added His useful tables, illustrative of Indian History, Chronology, Modern Coinages, Weights, Measures, etc London, J. Murray, vol 2, p 336

Pandit RS (1935) Kalhanas's Rajatarangini. India Press, Delhi, p 643

Ramsey CB (2009) Dealing with outliers and offsets in radiocarbon dating. Radiocarbon 51(3):1023-1045

Sahni DR (1918) Pre-Mohammadan monuments of Kashmir, 49-79. In: Marshall J (ed) Archaeological report 1915-1916. Government Printing Press, Calcutta, Archaeological Survey of India

Seeber L, Gornitz V (1983) River profiles along the Himalayan arc as indicators of active tectonics. Tectonophysics 92:335-467. doi:10.1016/0040-1951(83)90201-9

Sewell R, Dikshit SB (1896) The Indian calendar. Swan Sonnenshein, London, p 169

Stansbie JH (1908) Iron and steel. D. Van Nostrand, p 375

Stein A (1892) Kalhana's Rajatarangini, or chronicle of the kings of Kashmir, Sanskrit text with critical notes. Education Society's Press, Bombay, p 296

Stein A (1898) Kalhana's Rajatarangini: a chronicle of the kings of Kashmir, vol 2. Constable and Co, Calcutta

Stein A (1897) Notes on maps of ancient Kasmir and Srinagar. - [Paris] : Impr Nat, pp 75-85

Stein A (1899) Ancient geography of Kashmir. J Assoc Soc Bengal 68, Part 1 1-231, and Extra No. 2 (3 maps)

Tarikh-i-Hassan (1896) compiled by Pir Ghulam Hassan Khuihami, Kashmir series of texts and studies, 82, vol. 2. Research and Publication Department, Jammu and Kashmir Government, Srinagar (1954 reprint)

Vigne GT (1844) Travels in Kashmir, Ladak and Iskardo, the countries adjoining the mountain course of the Indus, and the Himalaya, north of Panjab, with map, 2nd edn, vol. 1, p 406. H. Colburn, London

Vörösmarty CJ, Fekete B, Tucker BA (1998) River discharge database, Version 1.1 (RivDIS v1.0 supplement). Available through the Institute for the Study of Earth, Oceans, and Space, University of New Hampshire, Durham NH (USA)

Walder JS, O'Connor JE (1997) Methods for predicting peak discharge of floods caused by failure of natural and constrcuted earthen dams. Water Resour Res 33:2337-2348

Wetlands International (2007) Comprehensive management action plan for Wular Lake, Kashmir, p 221. A-25, (2nd Floor), Defence Colony, New Delhi-110 024 